\title{
Clean Energy Technologies: Dynamics of Cost and Price
}

\author{
Gunther Glenk \\ School of Business, University of Mannheim \\ glenk@uni-mannheim.de \\ Rebecca Meier \\ School of Business, University of Mannheim \\ rmeier@mail.uni-mannheim.de

\section{Stefan Reichelstein} \\ School of Business, University of Mannheim \\ Graduate School of Business, Stanford University \\ reichelstein@uni-mannheim.de
}

April 2021 


\begin{abstract}
The rapid transition to a decarbonized energy economy is widely believed to hinge on the rate of cost improvements for certain clean energy technologies, in particular renewable power and energy storage. This paper adopts the classical learning-by-doing framework of Wright (1936), which predicts cost (price) to fall as a function of the cumulative volume of past deployments. We examine the learning rates for key clean energy system components (e.g., solar photovoltaic modules) and the life-cycle cost of generating clean energy (e.g., wind energy and hydrogen obtained through electrolysis). Our calculations point to significant and sustained learning rates, which, in some contexts, are much faster than the traditional $20 \%$ learning rate observed in other industries. Finally, we argue that the observed learning rates for individual technologies reinforce each other in advancing the transition to a decarbonized energy economy.
\end{abstract}

Keywords: learning-by-doing, renewable energy, energy storage, electrolysis, levelized cost of energy 


\section{Introduction}

A growing chorus of voices from the scientific community, policymakers, and business leaders point to climate change as an ever more urgent threat to the stability of the world's biosphere and, hence, to economic prosperity. At the same time, the global economy has thus far failed to bend the curve of carbon dioxide $\left(\mathrm{CO}_{2}\right)$ emissions, at least until the beginning of the Covid19 pandemic in 2020 (Le Quéré et al. 2020). Bending this curve would be a modest first step towards staying within the remaining "carbon budget" that the Intergovernmental Panel on Climate Change (IPCC) assesses as being compatible with the 1.5 degree Celsius $\left({ }^{\circ} \mathrm{C}\right)$ increase in global temperature relative to pre-industrial levels. Specifically, the IPCC has assessed a two-thirds chance that the global average temperature increase could be limited to $1.5^{\circ} \mathrm{C}$ if the world's cumulative anthropogenic carbon emissions from 2019 onward are kept below 420 billion metric tons of $\mathrm{CO}_{2}$ (Rogelj et al., 2018). With many governments and corporations now having adopted a goal of net-zero emissions by 2050, the world is likely to exceed that carbon budget by a significant margin, even if it were to succeed in charting a linear path for emissions reductions from the recent 2019 level of 42 billion metric tons of $\mathrm{CO}_{2}$ to zero emissions by 2050 1

A more lenient ceiling value for the global temperature increase set somewhere in the $1.5-2^{\circ} \mathrm{C}$ range would allow for correspondingly larger carbon budgets, but even for those scenarios, it is far from clear that the required global decarbonization process can be completed in time $:^{2}$ The central issue in this context is whether the economics of carbon-free energy technologies that are currently commercially viable is improving sufficiently fast. Some prominent observers have expressed skepticism in this regard and instead point to a need for technological innovations that represent "breakthroughs" rather than continued incremental improvements (Gates, 2021). Our analysis in this paper speaks to that debate by quantifying the observed learning rates for several energy generation and storage technologies. Specifically, we compare the rate of economic progress for solar photovoltaic (PV) power, onshore wind power, lithium-ion batteries, and hydrogen production through water electrolysis. These technologies are currently already central to the transition away from

\footnotetext{
${ }^{1}$ The simple calculation here is that with a linear decline path the cumulative amount of emissions by the year 2050 would be $42 \cdot(2050-2019) \cdot \frac{1}{2}=651$ billion tons of $\mathrm{CO}_{2}$ emissions.

${ }^{2} \mathrm{In}$ order to have a two-thirds chance of keeping the global average temperature increase below $2^{\circ} \mathrm{C}$, the IPCC scientists have identified a remaining carbon budget of 1,170 billion metric tons of $\mathrm{CO}_{2}$ (Rogelj et al., 2018).
} 
fossil fuels.

The well-known graph reproduced in Figure 1 is commonly attributed to R. Swanson, the former CEO of the solar company SunPower. Swanson (2011) simply plotted the selling prices of solar photovoltaic PV modules (measured in 2010 dollars) per Watt of peak power against the cumulative number of solar PV modules produced since 1978. With both cumulative volume, $Q$, and prices, $P$, measured on a logarithmic scale, Figure 1 demonstrates a statistically near-perfect relation corresponding to a constant elasticity learning curve, frequently attributed to Wright (1936):

$$
P=a \cdot Q^{-b}
$$

or, equivalently $\ln (P)=\ln (a)-b \cdot \ln (Q) !^{3}$ Importantly, if the estimated slope coefficient is $b=0.322$, then with every doubling of cumulative output the corresponding price per module is only $80 \%$ of the previous price prior to the doubling because $2^{-0.322} \approx 0.80$. Accordingly, the graph in Figure 1 is commonly referred to as the $80 \%$ learning curve, with a corresponding learning rate of $20 \% \square^{4}$

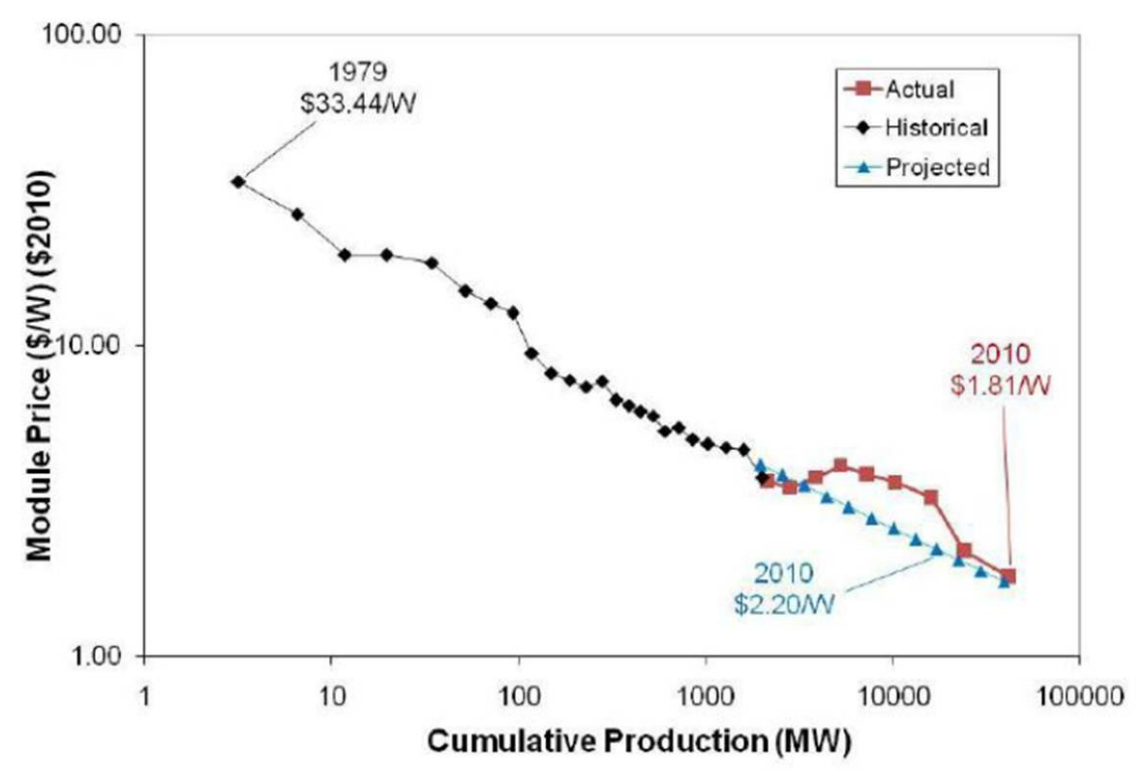

Figure 1: Historic solar PV module prices.

\footnotetext{
$\overline{3}$ Wright $(1936)$ documented a corresponding constant elasticity relationship between the cumulative number of aircraft frames produced and the number of labor hours required for the next airframe.

${ }^{4}$ There was a temporary bump in solar PV module prices in the years leading up to 2010, which was widely attributed to a shortage of the essential raw material polysilicon. By the end of 2010, average sales prices had virtually caught up with the values predicted by the $80 \%$ learning curve.
} 
The management literature and studies in industrial organization have examined alternative models of technological progress and the main drivers underlying such progress (Porter, 1990; Tirole, 1988; Lieberman, 1984). For instance, the widely acclaimed Moore's Law (named after the former CEO of Intel Corporation) in connection with semiconductor devices refers to the number of transistors on a chip doubling every two years, leading to the recursive relation $T(n+2)=2 \cdot T(n)$. Here, $T(\cdot)$ represents the number of transistors and $n$ the number of years $5^{5}$

The key difference between that approach and the above constant elasticity model is that technological progress is an exogenous function of time in Moore's formulation, while in the "Wright" formulation the rate of progress is endogenous and driven by the rate of product deployment. The implications for the clean energy transition and climate change are fundamental. In Wright's formulation, deployments of a clean energy technology not only have an immediate effect in terms of decarbonizing a slice of the current energy system but also a future learning effect in terms of bringing down the cost of future deployments of the same technology. Our empirical estimates confine attention to the constant elasticity learning curve framework, without seeking to validate that framework relative to alternative models of technological progress.

For the energy technologies considered in this paper, we first estimate the price dynamics of key system components, e.g., the modules for solar PV power systems or the electrolyzer unit for hydrogen production. Overall, we find that the prices of these key system components exhibit learning rates in the range of about 9-39\%. Accordingly the estimated learning rates are such that $0.09 \leq 1-2^{-b} \leq 0.39$. In particular, we observe that the rate of learning is slowest for onshore wind turbines during the years 1983-2019 at 9\%, and fastest for solar PV modules at a rate of 39\% for the years 2011-2019, almost double the estimated $20 \%$ learning rate in Swanson's chart shown in Figure 1. In interpreting this finding, it is essential to recall that the learning curve focuses on prices rather than the underlying manufacturing cost. The analysis in Reichelstein and Sahoo (2018) suggests that the sharp decline in photovoltaic modules in the years 2008-2013 was only partially attributable to declines in manufacturing costs.$^{6}$ During that time the PV module industry also went through considerable structural changes, with Chinese manufacturers expanding manufacturing capacity at a rapid pace.

\footnotetext{
${ }^{5}$ In recent years, some observers have voiced doubt about the continued relevance and applicability of Moore's Law in the context of computer chips, prompting the prediction that the number of people who doubt the validity of Moore's Law is now doubling every two years; see, for instance, Hayes (2018).

6 Reichelstein and Sahoo (2018) estimate that the cost of manufacturing modules declined at a rate of $38 \%$.
} 
The consequence of this structural industry change was that equilibrium prices no longer covered the full product cost of the goods produced, thus confounding the interpretation of the observed price declines (Reichelstein and Sahoo, 2018).

The second part of our analysis applies the constant elasticity learning model to the socalled Levelized Cost of Energy (MIT, 2007). In the context of power generation, this cost measure is frequently abbreviated as LCOE, with $E$ standing for electricity. Analysts rely on this unit cost measure expressed in dollars per kilowatt-hour (kWh) to rank different generation technologies such as fossil fuel versus renewable power plants. While the LCOE is sometimes simplistically conceptualized as Total Lifetime Cost Divided by Total Lifetime Energy, the significance of this metric is that, properly defined, it yields a break-even value (Reichelstein and Rohlfing-Bastian, 2015). Investors who sell every unit of energy produced during the lifetime of the asset for LCOE dollars per kWh will break even on their investment after incurring capital expenditures, ongoing operating costs, and accounting for applicable corporate income taxes.

We find that the LCOE of solar photovoltaic and onshore wind energy for the years 20102019 exhibited learning rates of about $40 \%$ both in Germany and in California. For solar power, this rate is comparable to that estimated for the prices of photovoltaic modules. In contrast, the learning rate for the LCOE of wind energy is much higher than the learning rate attributed to the system prices for wind turbines alone. The explanation for the faster decline in the LCOE values is the emergence of significant "denominator effects", reflecting that technological progress has also increased the capacity utilization rates for a given solar and wind resources. In the context of solar PV, higher capacity utilization reflects improvements in the efficiency of solar cells as well as better equipment such as the use of trackers Bolinger et al., 2020). For wind power, the improvement in capacity factors has been even more significant, owing to larger rotor blades and improved materials, which enable the turbines to keep (or start) spinning at lower wind speeds (Wiser et al., 2020). Finally, the "lifetime energy measure" in the denominator of the LCOE expression is increasing in the applicable discount factor, a variable that has also been increasing in the face of a lower cost of capital for renewable energy (Steffen, 2020).

Our analysis also estimates a learning curve for the life-cycle cost of producing hydrogen via electrolysis where electricity splits water into its constituent atoms of hydrogen and oxygen. The corresponding cost measure here is the levelized cost of hydrogen (LCOH) 
(Glenk and Reichelstein, 2021b). We find that for hydrogen the cost improvements over time are again compounded by the interaction between a numerator effect reflecting the declining prices for electrolyzers and a denominator effect corresponding to a lower cost of capital. In addition, an increase in the volatility of electricity prices, which represents a variable cost of producing hydrogen, tends to lower the $\mathrm{LCOH}$. Unlike the capacity factors of wind and solar PV, which are given exogenously, electrolyzers can be idled during periods of high electricity prices. As a consequence, higher volatility of electricity prices, accompanied by constant or decreasing average values, tends to lower the overall life-cycle hydrogen production.

The remainder of the paper is organized as follows. Section 2 analyzes the dynamics of system prices for four different clean energy technologies. Section 3 goes beyond system prices and integrates additional cost drivers by means of exploring the levelized cost of providing energy via solar PV, onshore wind, or hydrogen electrolysis installations. Section 4 concludes with a broader perspective on synergies across different clean energy technologies and the implications for a decarbonized energy economy.

\section{Dynamics of System Prices}

\subsection{Solar Photovoltaic Modules}

The globally installed capacity of solar PV systems has grown from 4 megawatts (MW) in 1976 to 627,000 MW in 2019 (IEA, 2020b). Initially, most solar PV systems were smallersized rooftop installations, before utility-scale facilities began to account for the majority of annual capacity additions. For the 114 GW of solar PV installations in 2019, for instance, $61 \%$ were utility-scale, while commercial and industrial facilities accounted for $24 \%$, and the remaining $15 \%$ were residential rooftop systems.

Solar photovoltaic systems comprise an array of PV modules and the so-called balance of system (BOS) components. While the modules consist of individual solar cells that convert solar insolation to electricity, the BOS components comprise the power inverter, other electronic parts, wiring and cabling, and installation labor. Increasing standardization of individual components and the growing scale of solar PV facilities have allowed the BOS prices to decline as well, albeit at a smaller rate than the prices of modules (IRENA, 2020).

The manufacturing process of crystalline silicon PV modules involves five major sequential steps: (i) purification of metallurgical silicon into polysilicon, (ii) growth of polysilicon 
ingots, (iii) slicing of ingots into wafers, (iv) lithographic layering of wafers to obtain photovoltaic cells, and (v) assembly of cells to modules (Lux Research, 2012). Continued process refinements at each of these steps have reduced the share of defective cells, the amount of polysilicons waste, the number of required manual labor hours. For instance, the reduction of silicon waste in step (iii) resulted from the use of thinner wire saws (Reichelstein and Sahoo, 2018). Process automation has significantly lowered the amount of manual labor required and increased the overall throughput of the factories.

To measure the learning effects associated with manufacturing PV modules, we adopt Wright's framework based on global average sales prices per Watt (W) of peak power capacity, thus extending the Swanson chart in Figure 1 past 2010. Our data source for this calculation is based on BNEF (2019a) and covers the years from 1976-2019. Specific values for yearly module prices and installation capacity are listed in Table A1 of the Appendix.

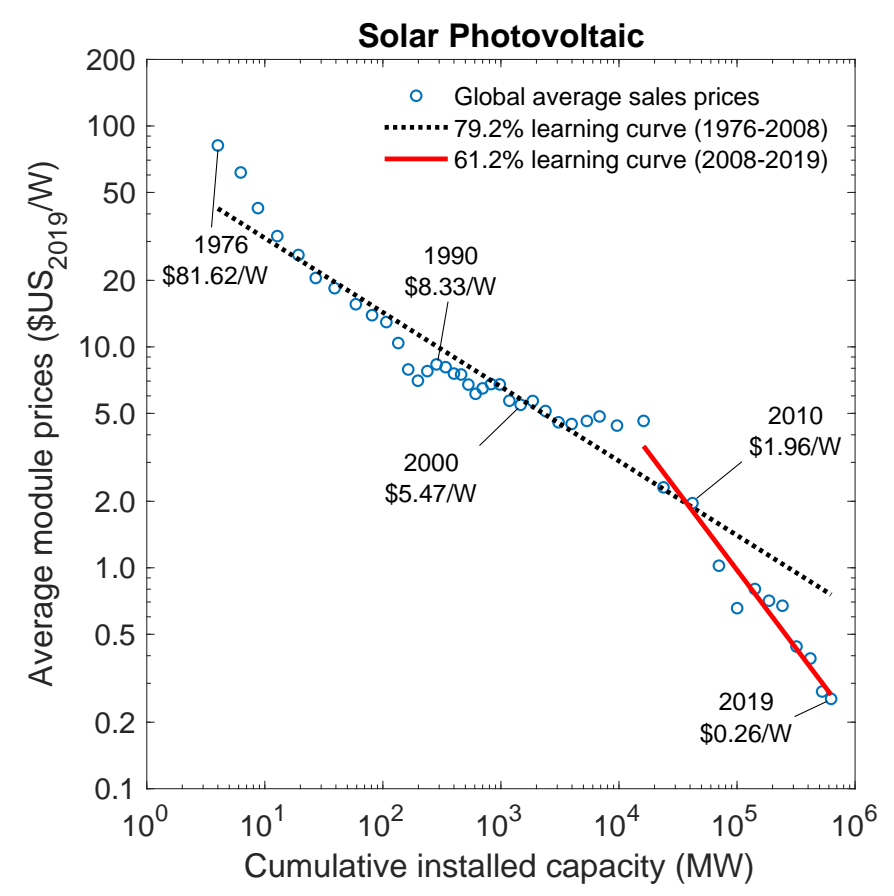

Figure 2: Price dynamics of solar PV modules.

Figure 2 plots the (logarithm of) global average sales prices for solar PV modules against the (logarithm of) global cumulative installation capacity measured in megawatts. Average sales prices for PV modules have fallen almost monotonically from $\$ 81.62 / \mathrm{W}$ in 1976 to $\$ 0.26 / \mathrm{W}$ in 2019. In a minor variant of Swanson's graph shown in Figure 1, we estimate that the observed price declines are best described by a $79.2 \%$ constant elasticity learning 
curve for the time window 1976-2008. The corresponding $R^{2}$ coefficient for this regression is 0.89 .

For a separate regression starting in 2008, however, we observe that module prices dropped much faster than suggested by the historical $80 \%$ learning curve. In fact, for the years $2008-$ 2019 we estimate a learning rate of $38.8 \%\left(R^{2}=0.95\right)$. Earlier studies on the price dynamics of solar PV modules have identified learning rates anywhere in the range of $10-40 \%$ Rubin et al. 2015). As suggested by Figure 2, the main reason for this variation appears to be the selection of the time window considered. Some of the earlier studies were based only on data from specific geographic regions (Yeh and Rubin, 2012). Furthermore, currency fluctuations may have had a significant effect on the resulting parameter estimates. Lilliestam et al. (2020), for instance, find that the choice of currency choice can lead to differences in the estimated learning rates of up to 16 percentage points.

Many industry analysts have linked the recent steep decline in the prices for photovoltaic modules not only to underlying cost reductions but also to a changing industry landscape characterized by a dramatic increase in the industry's aggregate manufacturing capacity. To track the dynamics of the cost of manufacturing crystalline silicon photovoltaic modules, Reichelstein and Sahoo (2018) examine the financial statements of about a dozen firms for the years 2008-2013. During that time window, all of the firms in the samples were "pureplay" module manufacturers. Thus, they had no other significant production activities and, therefore, accounting figures like Cost of Good Sold and Finished Goods Inventory refer only to modules produced and sold by the firm in a particular year.

For the years 2008-2013, Reichelstein and Sahoo (2018) estimate the long-run marginal cost (LMC) of manufacturing solar photovoltaic modules based on firms' annual reports and industry-level data about module prices and volume. Conceptually, the importance of the LMC is that firms would exactly break even on their investments (achieve a net present value of zero) if modules were to be sold at the current LMC of that year. Furthermore, in a competitive industry in which firms are price takers, the predicted equilibrium price is equal to the LMC in each period. Figure 3 depicts the actual average module sales prices, the estimated long-run marginal cost, and the "traditional" $80 \%$ learning curve. Importantly, actual sales prices were consistently below the estimated LMC, except for a brief period between late 2009 and early 2011. This finding is consistent with the fact that for the years 2008-2013 time window, solar PV manufacturers generally reported negative accounting 
profits $]^{7}$ The common explanation for prices below the long-run marginal cost during those years is that Chinese manufacturers greatly expanded the production capacity available in the industry during the recessionary phase of the financial crisis.

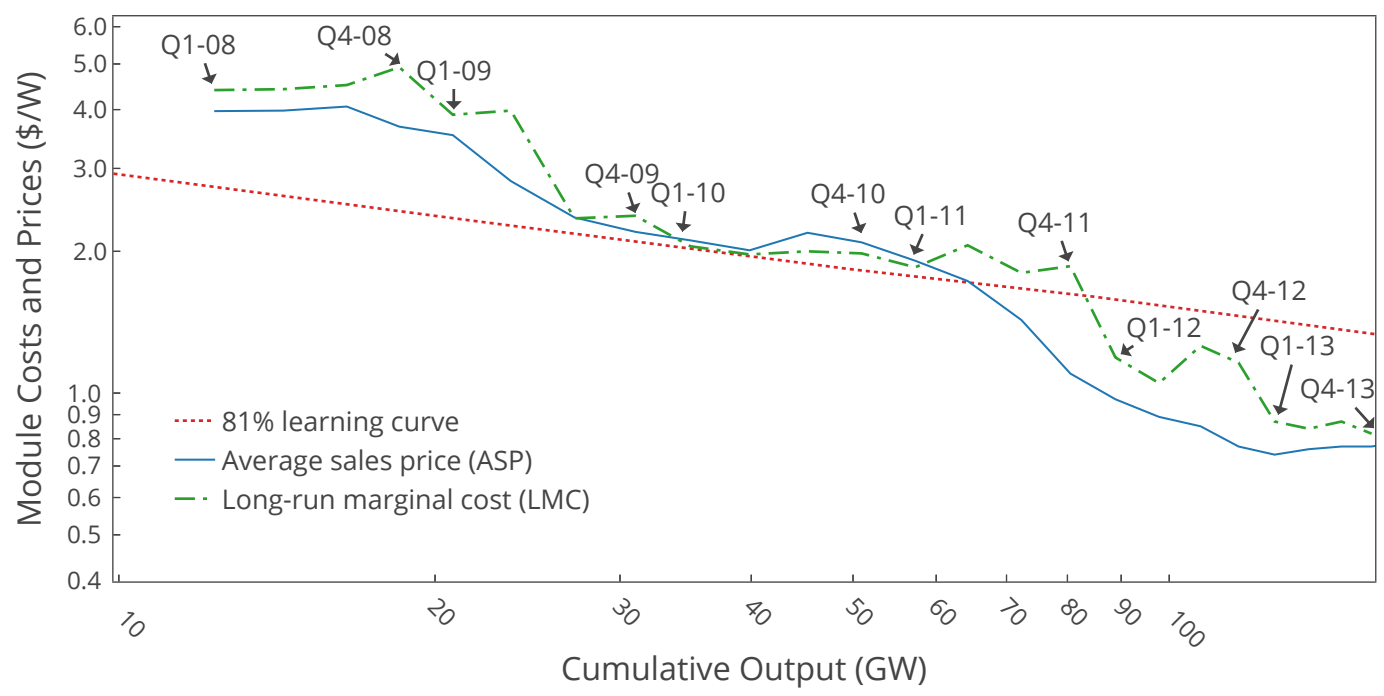

Figure 3: Average sales prices and long-run marginal costs of solar PV modules.

Overall, the LMC trajectory in Figure 3 indicates that for the years 2008-2013, both module prices and unit manufacturing costs declined at a faster rate than predicted by the traditional 80\% learning curve. Reichelstein and Sahoo (2018) estimate the cost dynamics for two components of the long-run marginal cost of solar PV manufacturing: capacity-related cost for machinery and equipment, and core manufacturing costs for materials, labor, and overhead. Based on quarterly financial statements from a subset of module manufacturers and quarterly data from an industry analyst, the authors infer a 38\% constant elasticity learning rate for core manufacturing cost. Capacity-related costs for machinery and equipment were found to have declined at a rate of about $24 \%$ per year, again exceeding the traditional long-run $20 \%$ learning rate. While it would be important to extend this analysis beyond 2013, the inference from publicly observable accounting data has become far more difficult because most of the leading firms have now expanded their product offerings beyond solar PV modules.

Earlier studies on the price dynamics of PV modules have considered potential drivers of learning other than cumulative production volume. Additional potential explanatory variables include raw material prices (e.g., polysilicon and silver), the scale of manufacturing ${ }^{7}$ The LMC includes a charge for the opportunity cost of capital. Therefore, negative accounting profits imply, at least in theory, that prices were below the LMC (Reichelstein and Sahoo, 2018). 
capacity, the number of patents associated with the technology, and expenditures for research and development (Kavlak et al., 2018; Yu et al., 2011; Miketa and Schrattenholzer, 2004). The general finding in these studies is that, while other explanatory variables can be statistically significant, these have generally only a minor impact on the estimated coefficient associated with cumulative production volume (Lieberman, 1984; Preston and Keachie, 1964). In particular, when estimating the $62 \%$ learning curve for core manufacturing costs during the years 2008-2013, Reichelstein and Sahoo (2018) control for the scale of the production facilities and substantial price declines in polysilicon. Without these control variables, their analysis yields a coefficient of $59 \%$ on cumulative volume over the same time period.

\subsection{Onshore Wind Turbines}

The pace of installations for onshore has also accelerated sharply over the past 30 years, growing from $8 \mathrm{MW}$ in 1980 to 650,000 MW in 2019 (Pitteloud, 2019). The most recent annual capacity additions have averaged about $50 \mathrm{GW}$. Onshore rather than offshore wind has thus far accounted for the majority of total annual capacity additions. Of the $61 \mathrm{GW}$ of newly installed wind capacity in 2019, approximately 55 GW were built onshore (Pitteloud, 2019; GWEC, 2019).

Wind turbines consist of a steel tower, a rotor with blades, and a nacelle containing the drivetrain, a converter and transformers. In contrast to solar PV systems, these components combine both the power generation unit and the BOS components. The steel tower, the nacelle, and the rotor blades are typically constructed individually at the production site of the turbine manufacturer and then transported to and assembled at the location where the wind turbine is to be raised (EERE, 2020).

Cost reductions for wind turbines mainly originated from technological improvements that enabled turbine manufacturers to significantly increase wind tower heights and blade lengths. Advanced turbine control systems now make it possible to manage the additional thrust at greater tower heights and to allow for a smooth operation at peak efficiency under conditions of varying wind speeds (Thresher et al., 2008). In general, larger turbines entail larger costs for material and transportation, but also deliver a larger peak power generation capacity. The resulting system prices per Watt of capacity installed have declined.

We calibrate Wright's framework based on the global average system price per Watt of peak capacity for installed onshore wind turbines. In addition to the market prices for the 
turbines, the system prices comprise the cost of installation, grid connection, and project development (IRENA, 2020). The requisite data are available over a long time horizon and on a global level. Specifically, we rely on data by IRENA $(2020)$ for the turbines, and on cumulative Wind Power Statistic of the World Wind Energy Association for installed capacity (Pitteloud, 2019). Details are provided in Table A1 in the Appendix.

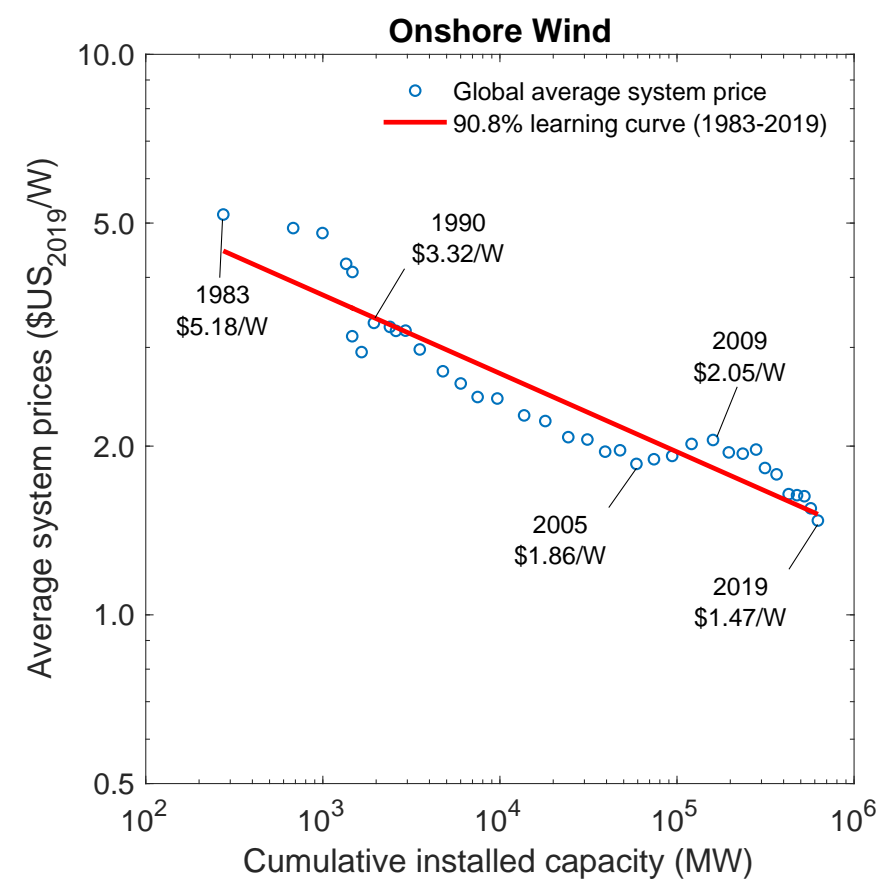

Figure 4: Price dynamics of onshore wind turbines.

Figure 4 depicts the (logarithm of) global average system prices for onshore wind turbines as a function of the (logarithm of) global cumulative installed capacity. Average system prices have fallen from $\$ 5.18 / \mathrm{W}$ in 1983 to $\$ 1.47 / \mathrm{W}$ in 2019 . This price trajectory corresponds to a $90.8 \%$ learning curve $\left(R^{2}=0.89\right)$, implying that system prices declined by about $9 \%$ whenever cumulative installed capacity doubled. Thus, the learning rate for the system prices of wind turbines was less than half of that for solar PV modules. This comparison is, however, somewhat misleading since the figures for wind power systems also comprise the BOS components while our figures for solar power thus far only considered the modules.

The recent "spike" in turbine prices during the years 2005-2009 has been attributed to regulatory shocks about the extension of subsidies for wind energy in the United States and Europe (Bolinger and Wiser, 2012). Specifically, the main subsidy for wind energy in the United States, the federal Production Tax Credit, was widely expected to expire by the 
end of 2005. When the U.S. Congress agreed to extend this tax credit at relatively short notice, demand for wind turbines surged, allowing turbine manufacturers to charge a price premium. 8 With the arrival of the financial crisis in 2008/09, however, demand for wind turbines dropped again and competition among turbine manufacturers intensified, inverting the short-lived upward price trend (Bolinger and Wiser, 2012).

It would be desirable to identify the extent to which the decline in average system prices of wind turbines reflects a corresponding decline in the underlying production costs. Such an analysis, however, is made difficult by recent industry consolidations and the trend among turbine manufacturers to expand their product lines. The number of suppliers in this industry dropped from 63 in 2013 to 33 in 2019 (REN21, 2020). Furthermore, most major manufacturers for onshore wind turbines have other significant business segments, such as services for operation and maintenance, or the development of offshore wind parks. Their annual financial reports therefore do not provide sufficiently detailed segment information to analyze the cost of onshore wind turbines alone (Vestas, 2019, GE, 2019; SGRE, 2019; Goldwind, 2017).9 Industry analysts have argued that profit margins for turbine manufacturers have declined substantially in recent years (GWEC, 2019; Reuters, 2019). This decline has been partly attributed to the shift from feed-in-tariffs to competitive auction mechanisms in countries like China, Germany, and Denmark.

While our calculations point to a $9 \%$ constant elasticity learning curve for the market prices of wind turbines, earlier studies have yielded a range between $3 \%$ and $30 \%$ (Ibenholt, 2002; Junginger et al., 2005; Williams et al., 2017). We attribute this variation in significant part due to some studies examining country-specific learning curves based on national system prices and/or national capacity deployment (Lindman and Söderholm, 2012; Rubin et al. 2015; Williams et al., 2017; Hayashi et al., 2018). Additional variation results from studies that attempt to infer global average system prices based on data from a few select countries, e.g., the United States, Germany, or Denmark, which have recently deployed large amounts of wind energy (Isoard and Soria, 2001; Junginger et al., 2005; Neij, 2008). Some earlier studies have looked at global price and capacity data, but only for relatively short time windows (Jamasb, 2007; Nemet, 2009).

\footnotetext{
$8 \longdiv { 8 f i o n g }$ and Crispin (2007) report a tripling of one manufacturer's margins on earnings before interest and taxes in the period from $2005-2007$.

${ }^{9}$ Among the more than 30 firms that are active in this industry, the four leading players (Vestas, Siemens Gamesa, Goldwind, GE Renewables) had 55\% of total sales in 2019 (REN21, 2020). Furthermore, the leading players are also active in the offshore wind market and in other renewable energy segments.
} 


\subsection{Battery Packs}

Energy storage is generally viewed for a reliable energy supply based on intermittent and volatile power generation sources, such as wind and solar power (Baumgarte et al., 2020). Battery storage, in particular, has enormous application potential in the transition towards a decarbonized energy economy. In the transportation sector, inexpensive batteries are key to the electrification of road vehicles, as batteries currently account for about $35 \%$ of the sales price of an electric vehicle (BNEF, 2019a; Comello et al., 2021). With recent advances in battery technology, deployments of lithium-ion (Li-ion) batteries have become prominent in both stationary and mobile applications. In terms of global installed capacity, the energy storage capacity of batteries deployed has grown from 426 megawatt-hours (MWh) in 2010 to 351,000 MWh in 2019 (BNEF, 2019b; Schmidt et al., 2019). Electric vehicles have contributed substantially to this growth, with the number of vehicle registrations increasing from 19,000 in 2010 to 7.2 million in 2019 (IEA, 2020a).

Li-ion battery systems entail a battery pack that comprises an array of cells protected by a frame. The cells consist of an electrolyte, a separator, and an electrode typically based on graphite (SDI, 2021). A battery also requires balance of system components such as the electronic battery management system, electric connections, and a cooling system. Battery packs are the energy component of a battery, reflecting the total amount of energy that can be stored in the battery. The size of this component is measured in Watt-hours (Wh). In contrast, the power component of a battery, which comprises the remaining BOS parts, is measured in Watts and indicates the maximum rate of charge or discharge for the battery. In the context of an electric vehicle, the power component of a battery dermines the vehicle's ability to accelerate, while, the energy capacity determines the vehicle's maximum range on a single charge. The ratio of the energy to the power component is generally referred to as the duration of the battery. Duration thus indicates the number of hours for which the battery can charge/discharge at maximum power 10

Cost reductions for Li-ion battery packs have resulted from ongoing technological and process improvements at the five main stages of production: (i) manufacturing of the electrode, (ii) cell assembly, (iii) cell finishing, (iv) packing of cells into modules, and (v) aggregation of modules into packs (Heimes et al., 2018). Cost improvements have been attributed to technological advancements in battery cathode chemistry and materials, higher energy density,

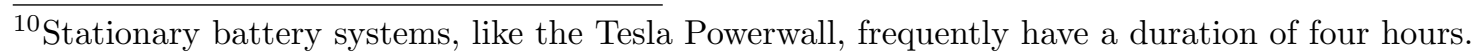


as well as reduced battery degradation rates. In addition, there have been improvements in the form of vertically integrated production steps that increased manufacturing efficiency. Furthermore, basic economies of scale through so-called gigafactories (Motors, 2014) appear to have further contributed to the overall cost and price decline in Li-ion battery packs (Tsiropoulos et al., 2018; Curry, 2017).

Our estimation of the learning rate for Li-ion battery packs relies on data shown in Table A1 in the Appendix. Prices are based on data from BNEF (2020) and Comello and Reichelstein (2019). Global cumulative capacity installation data have been obtained from BNEF (2019b) and Schmidt et al. (2019). Figure 5 depicts the resulting learning curve, again on a logarithmic scale. Between 2010 and 2019, average sales prices declined by almost $90 \%$ from $\$ 1.13 /$ Wh to $\$ 0.15 /$ Wh. The trajectory of observed market prices yields a $19.6 \%$ learning rate $\left(R^{2}=0.94\right)$.

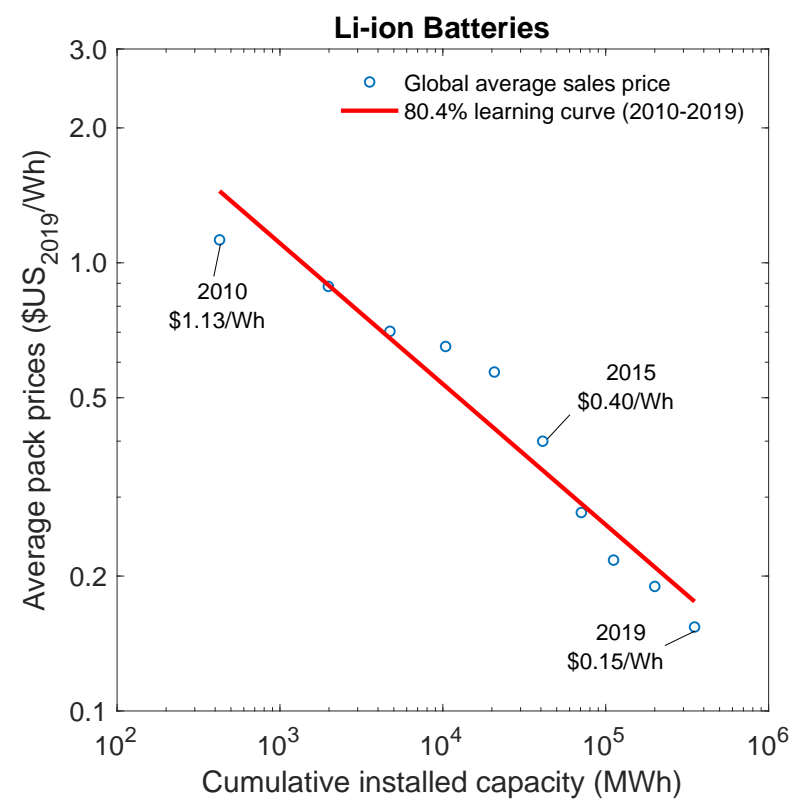

Figure 5: Price dynamics of Li-ion battery packs.

Since our analysis reported in Figure 5 focuses on Li-ion battery packs designed for largescale applications in automobiles and grid-level energy storage, we are confined to observations from 2010 onward. Data for battery packs in consumer electronics are available for a longer time. Such battery packs, however, have a different performance profile in terms of power-to-energy rating, charging and discharging speed, energy density, and longevity. As a consequence, they differ in several aspects, such as component materials, cell designs, cell 
packing, and hence their overall production costs.

Due to the relative novelty of Li-ion batteries in the power and mobility sector, there have thus far been only a few studies on the applicable learning rates. Based on global average sales prices between the years 2010-2016, Schmidt et al. (2017b), for instance, estimate an 84\% learning curve for Li-ion battery packs. Alternatively, Ziegler and Trancik (2021) calculate a learning rate of $24 \%$ for cylindrical Li-ion battery cells, which are the most common cell type for grid-level and automobile storage systems ${ }^{11}$ Furthermore, Kittner et al. (2017) examine how cumulative installation capacity in combination with the cumulative number of international patents drive the price decline of Li-ion battery cells of consumer electronics. For the time window 1991-2015, their two-factor estimation model estimates a $17 \%$ learning rate associated with cumulative capacity installations and a $2 \%$ price reduction per 100 patents registered by the Patent Cooperation Treaty.

\subsection{Electrolyzers}

The potential of hydrogen as a universal energy carrier has long been heralded. The gas can be used for energy storage and the subsequent production of heat and electricity (Staffell et al., 2019). Other important applications include hydrogen as a fuel for transportation and as a feedstock in chemical and processing industries. Widespread adoption of hydrogen in the energy system has so far been held back by the inability to produce the gas without carbon emissions and at low cost 12 Recent technological innovations in the form of water electrolysis, whereby (renewable) electricity infused in water splits the water molecule into oxygen and hydrogen (Davis et al., 2018), has renewed the interest in hydrogen 13

Leading electrolysis technologies in the market currently include polymer electrolyte membrane (PEM) electrolyzers, alkaline electrolyzers, and solid oxide cell electrolyzers (Staffell et al. 2019). Among those, PEM electrolyzers have exhibited the highest deployment rates in recent years (IEA, 2019). One advantage of PEM electrolyzers is their ability to ramp up and down quickly, thus allowing for an almost instantaneous absorption of surplus electricity from the grid during peak hours of renewable power generation. A PEM electrolyzer

\footnotetext{
${ }^{11}$ Adjusting for the substantial improvements in volumetric and gravimetric energy density of Li-ion cells, Ziegler and Trancik (2021) even identify a learning rate of $31 \%$ for cylindrical Li-ion cells.

${ }^{12}$ Industrial hydrogen production currently accounts for over $2 \%$ of annual global $\mathrm{CO}_{2}$ emissions (IEA, 2019).

${ }^{13}$ Such electrolytic hydrogen production is of obvious interest from the perspective of buffering the growing volatility in electricity markets resulting from the large-scale deployment of wind and solar energy installations (Olauson et al. 2016; Wozabal et al., 2016).
} 
consists of multiple electrolysis stacks, which are surrounded by a balance of system comprising thermal and fluid management, power electronics, and hydrogen treatment (Schmidt et al., 2017a). Each stack is made up of several cells in which two electrodes separated by a membrane split the water molecule into oxygen and hydrogen.

The production of PEM electrolyzers has thus far originated in customized contract manufacturing, and therefore been relatively labor intensive (Schmidt et al., 2017a). Some cost reductions have resulted from early efforts of standardization and automation of production processes as well as growing sizes of production plants. Technological advancements have further reduced overall input material cost and production waste. Examples of these advancements include improved electrode design, membranes and catalyst coating, and the substitution of expensive input materials with cheaper yet more efficient materials.

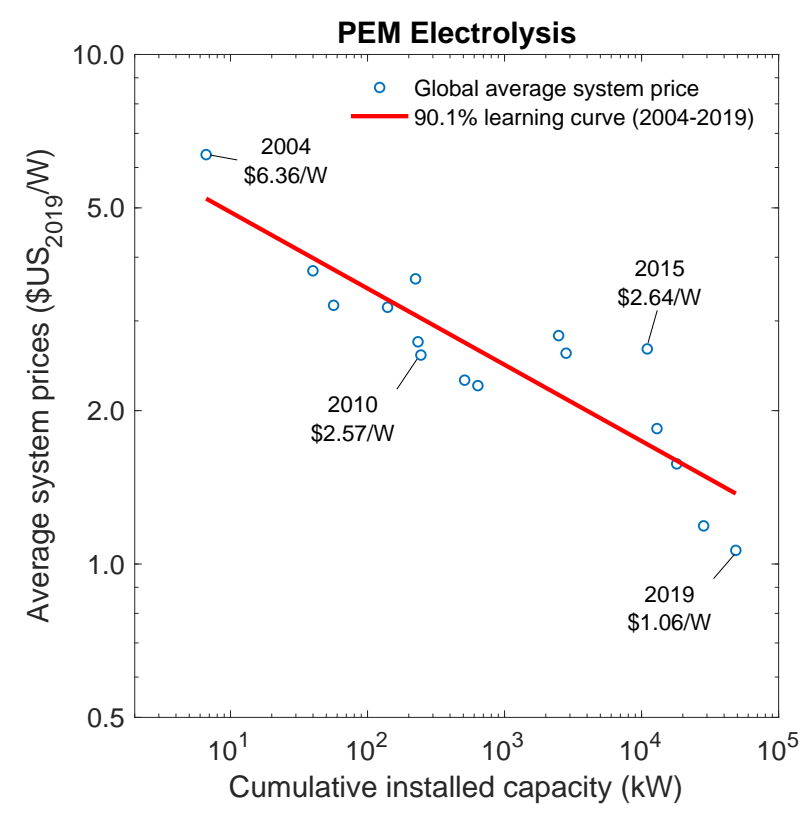

Figure 6: Price dynamics of PEM electrolyzers.

In estimating the learning curve for PEM electrolyzers, we rely on global average system prices that were hand-collected from journal articles, technical reports, and interviews with manufacturers (Glenk and Reichelstein, 2020). Data on cumulative capacity installations is based on a comprehensive review of Power-to-Gas electrolyzer facilities deployed around the world (IEA, 2019). Figure 6 shows the corresponding Wright (1936) learning curve. Prices have fallen from $\$ 6.36 / \mathrm{W}$ in 2004 to $\$ 1.06 / \mathrm{W}$ in 2019 . We estimate a $9.9 \%$ reduction in prices with every doubling of volume. The $R^{2}$ in this regression is 0.79 . Direct comparison 
of the graphs in Figures 2 6 shows that the prices of PEM electrolyzers exhibited greater variation from the projected trajectory, which we attribute to PEM electrolyzers becoming commercially viable only within the last 15 years.

\section{Dynamics of the Levelized Cost of Energy}

The economics of power generation facilities varies not only with the generation technology employed but also with the size and location of the facility. To capture and compare the unit economics of competing facilities, the energy literature has focused on life-cycle cost measures 14 In the context of electricity, this unit cost is frequently referred to as the levelized cost of electricity (LCOE). Expressed in dollars per kWh, the LCOE identifies the unit revenue that an investor in an energy facility would have to obtain on average over the useful life of the asset to break even in terms of discounted cash flows (MIT, 2007). As such, the LCOE allows for a cost comparison of alternative power generation technologies that differ in terms of their cost structure and operational characteristics across the lifetime of the asset, e.g., natural gas turbines vs. solar PV installations.

Following the concept development in Reichelstein and Rohlfing-Bastian (2015) and Comel o et al. (2017), the LCOE can be expressed as the sum of three components:

$$
L C O E=w+f+c \cdot \Delta
$$

Here, $w$ and $f$ denote the (levelized) variable and fixed operating costs per $\mathrm{kWh}$, respectively. These costs are either zero or minor for solar photovoltaic and wind power. The unit cost of capacity, $c$, is obtained by "levelizing" the initial systems price:

$$
c=\frac{S P}{8,760 \cdot C F \cdot \sum_{i=1}^{T} x_{i} \cdot\left(\frac{1}{1+r}\right)^{i}} .
$$

In the context of wind energy, the numerator, $S P$, in the definition of the unit cost of capacity refers to the cost of acquiring, installing, and connecting wind turbines (in $\$ / \mathrm{kW}$ ). Thus, our calculations below will refer back to the system prices shown in Figure 4 above. The levelization factor in the denominator is the product of two components. The product 8,760 $C F$ yields the effective number of hours per year that the facility is generating

\footnotetext{
${ }^{14}$ See, for instance, Lazard 2016, 2018, 2020) or NREL (2009).
} 
electricity at its nameplate capacity ${ }^{15}$ The scalar $\sum x_{i} \cdot\left(\frac{1}{1+r}\right)^{i}$ reflects the number of years the generation facility will be in operation $(T)$. This number is "discounted" at the applicable cost of capital, $r$, and the degradation factor, $x_{i}$, which reflects that the asset may diminish in productive generation capacity over time 16

Finally, the tax factor $\Delta$ quantifies the financial impact of corporate income taxes, the allowable depreciation schedule for tax purposes, and any applicable investment tax credits. For instance, the United States tax code currently grants an investment tax credit for solar PV installations and for energy storage systems, in particular batteries, that are installed in connection with solar systems (U.S. Department of Energy, 2016). This credit is calculated as a percentage of the system price that is deducted from the investor's income tax liability. Tax shields for debt financing are included in the calculation of the cost of capital as this number will be calculated as the weighted average cost of capital (Ross et al., 2008).

\subsection{Levelized Cost of Electricity}

We first examine the dynamics of the LCOE for utility-scale solar PV and onshore wind power installations in the context of California and Germany. Both jurisdictions have deployed considerable amounts of renewable energy in recent years, with utility-scale solar facilities being added since around 2010. By international comparison, California and Germany have moderate wind resources. In contrast to Germany, California enjoys a high degree of insolation.

Table 1 lists parameter values for the main input variables for the years 2010 and 2019 (details and data sources in the Appendix). System prices for solar PV include the market prices for modules, BOS components, and the cost of installation. Similarly, the acquisition cost of turbines and their installation comprise the system prices for wind energy. Our calculations rely on data collected from multiple sources including industry databases, technical reports, and journal articles. A comprehensive list of all input and output variables is provided in the Appendix.

While the overall system prices for both photovoltaic systems and wind turbines have declined dramatically between 2010 and 2019, different components declined in price at

\footnotetext{
${ }^{15}$ For solar PV and wind energy, the scalar capacity factor $C F$ is exogenously given by the availability of solar insolation or wind speed in a particular location, assuming the facility will always generate electricity at the maximum rate available.

${ }^{16}$ For instance, the efficiency of solar PV modules was observed to decay at a constant annual rate of about $0.5 \%$ (Jordan and Kurtz, 2013).
} 
Table 1: Cost parameters for renewable energy sources.

\begin{tabular}{lcc|cc}
\hline & \multicolumn{2}{c}{ California } & \multicolumn{2}{c}{ Germany } \\
in 2019 \$US & 2010 & 2019 & 2010 & 2019 \\
\hline Solar PV & & & & \\
System price $(\$ / \mathrm{kW})$ & 5,396 & 1,343 & 3,705 & 899 \\
Fixed operating cost $(\$ / \mathrm{kW})$ & 14.03 & 8.81 & 35.51 & 7.34 \\
Capacity factor (\%) & 21.04 & 28.69 & 7.44 & 10.80 \\
Cost of capital (\%) & 6.04 & 4.50 & 4.60 & 2.00 \\
Useful lifetime (years) & 30 & 30 & 30 & 30 \\
Federal tax rate (\%) & 35.00 & 21.00 & 30.00 & 30.00 \\
Onshore Wind & & & & \\
System price $(\$ / \mathrm{kW})$ & 2,927 & 1,678 & 2,271 & 1,762 \\
Fixed operating cost $(\$ / \mathrm{kW})$ & 28.75 & 21.94 & 73.00 & 48.88 \\
Capacity factor (\%) & 27.84 & 34.70 & 24.00 & 31.10 \\
Cost of capital (\%) & 6.04 & 4.50 & 4.60 & 2.00 \\
Useful lifetime (years) & 30 & 30 & 30 & 30 \\
Federal tax rate (\%) & 35.00 & 21.00 & 30.00 & 30.00 \\
\hline
\end{tabular}

different rates. For solar photovoltaic systems, for instance, the decline in PV module prices was diluted by BOS costs falling at a slower rate 17 Specifically, the relative share of modules within the total system price declined from $41.7 \%$ in 2010 to $25.6 \%$ in 2019 (IRENA, 2020. $\mathrm{BNEF}, 2019 \mathrm{~b})$. One cause of this shift is the increasing deployment of axis trackers (Bolinger et al. 2020). Yet, by enabling PV modules to track the sun over a day, the addition of trackers also yielded an increasing capacity factor, $C F$, in the denominator of the unit of capacity in equation (3). For wind turbines, capacity factors also increased mainly as a result of the growing turbine towers and rotor blades, which allows the turbines to convert wind at higher altitudes and lower wind speeds.

Table 1 also indicates that the cost of capital for renewable energy investments decreased substantially over the past decade (Steffen, 2020). This reduction can be attributed not only to the recent decline in interest rates but also to the fact that over time debt and equity investors appear to require a lower risk premium for renewable energy investments (Egli et al., 2018). A lower cost of capital in the denominator of the unit capacity cost $c$ in equation (3) again contributes to a lower LCOE. Finally, the U.S. federal government implemented two changes to the federal tax code that came into effect in 2018: the corporate

\footnotetext{
${ }^{17}$ Louwen and van Sark (2020), for instance, find that the reduction in the cost of balance of system components for utility-scale solar PV plants in Germany is described by an $88 \%$ learning curve for the years 2006-2017.
} 
income tax rate was lowered from $35.0 \%$ to $21.0 \%$, and upfront capacity expenditures for new energy facilities can be depreciated fully in the year of investment (U.S. IRS, 2019).

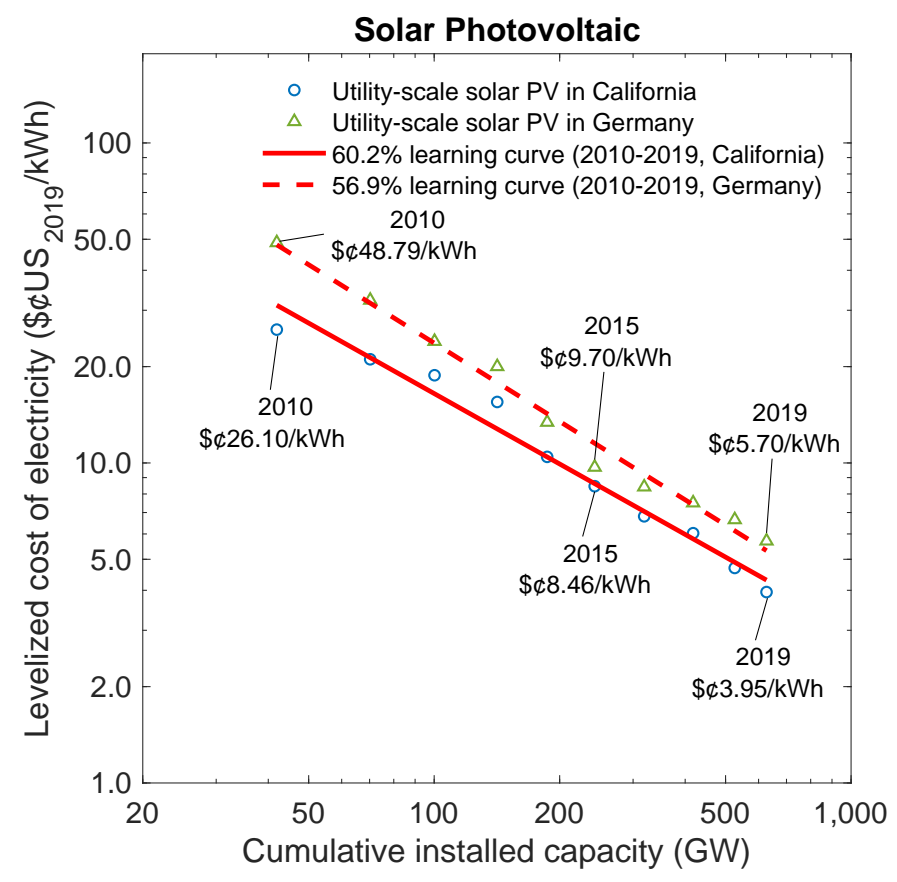

Figure 7: LCOE Dynamics: Solar Power

The trajectory of the logarithmic LCOE values for utility-scale solar PV in California and Germany are shown in Figure 7. As before, we plot these values as a function of cumulative capacity installations, even though there has been little empirical support for the notion that all components of the LCOE are described reasonably well according to the Wright framework. In fact, for certain components, such as the capacity factor, $C F$, it appears unlikely that this variable evolves as a constant elasticity function of cumulative volume. Nonetheless, Figure 7 indicates that the aggregate LCOE values for the decade spanning the years 2010-2020 conform quite closely to a $60.2 \%$ learning curve in California $\left(R^{2}=0.97\right)$ and a $56.9 \%$ learning curve in Germany $\left(R^{2}=0.99\right)$. We regard it as a coincidence that the predicted learning for the LCOE of solar PV power is almost identical to that for solar modules alone, as shown for the decade 2008-2019 in Figure 2. We note that the values in Figure 7 exclude public policy support that is available for solar installations in California through the federal investment tax credit and in the form of a feed-in premium in Germany ${ }^{18}$

\footnotetext{
${ }^{18}$ Accounting for the investment tax credit, our calculations yield LCOE values in California of $\$ c{ }_{1} 16.42 / \mathrm{kWh}$ in 2010 and $\$ c \% 2.66 / \mathrm{kWh}$ in 2019.
} 
The differences in LCOE values between the two jurisdictions thus mainly stem from better solar insolation factors and hence higher capacity factors in California.

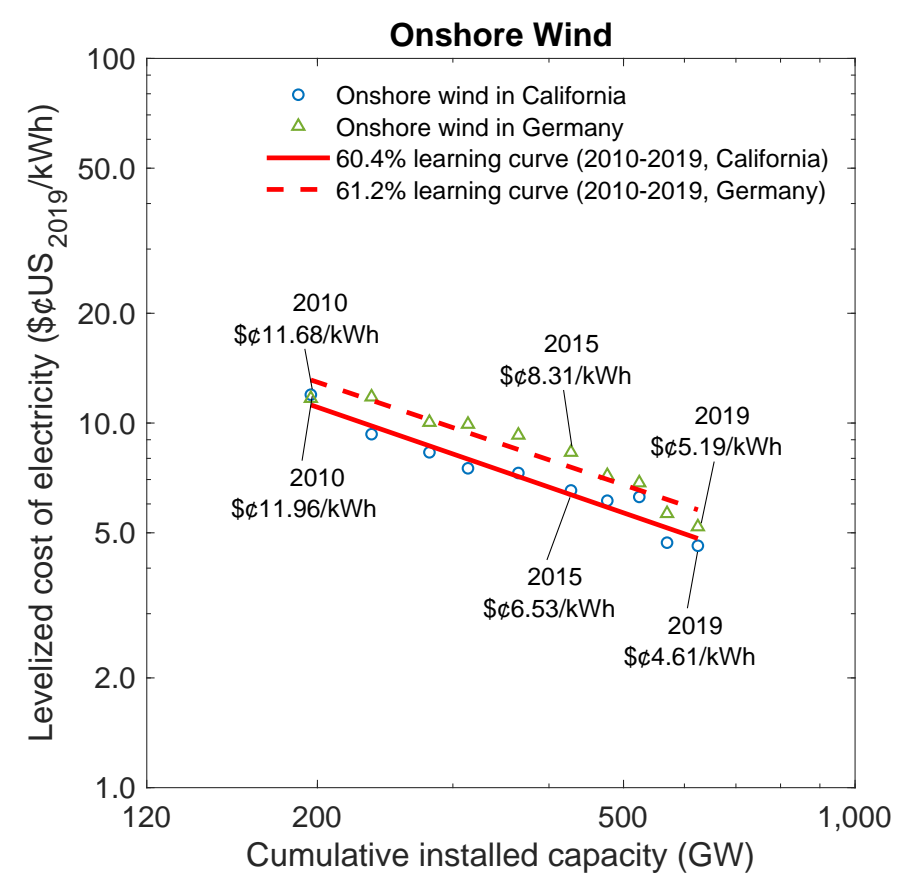

Figure 8: LCOE Dynamics: Wind Power

Figure 8 plots the equivalent of Figure 7 for onshore wind capacity. In California, the LCOE values declined from $\$ c 11.96 / \mathrm{kWh}$ in 2010 to $\$ \mathrm{c} 4.61 / \mathrm{kWh}$ in 2019 , and from

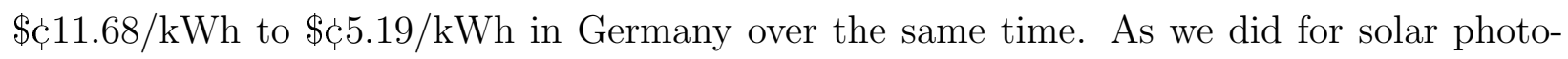
voltaic systems, public subsidies for wind energy are again excluded in both jurisdictions 19 The relatively small difference between LCOE values for the two jurisdictions result primarily from higher fixed operating costs in Germany, partially compensated by a lower cost of capital.

Our finding of a $60.4 \%$ learning curve in California $\left(R^{2}=0.94\right)$ and a $61.2 \%$ learning curve in Germany $\left(R^{2}=0.92\right)$ for onshore wind is surprising in light of our earlier finding, reported in Figure 4, that between 1983-2019 wind turbines experienced "only" a 90.8\% learning curve in terms of system prices. One explanation for the much faster drop in LCOE values is that the regression analysis underlying Figure 8 is based on a much shorter time

\footnotetext{
${ }^{19}$ Some studies include the production tax credit that is available for wind energy facilities in the U.S. in the calculation of the LCOE. Accounting for this credit, our calculations yield LCOE values in California

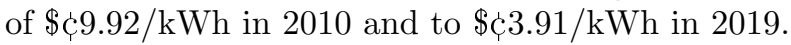


horizon ${ }^{20}$ A second explanation for the faster drop in the LCOE is through the denominator in equation (3). Here, capacity factors have increased sharply due to better building materials resulting in higher yields of converting wind energy into electric power. Finally, our data sources indicate that the weighted cost of capital for wind projects declined significantly and thereby increased the term $\sum_{i=1}^{T} x_{i} \cdot\left(\frac{1}{1+r}\right)^{i}$ in equation (3).

Our estimates of the LCOE dynamics shown in Figure 7 and 8 is generally consistent with LCOE values reported by industry analysts and academic studies; see, for instance, (Bolinger et al., 2020; Wiser et al., 2020; Kost and Schlegl, 2010; Kost et al., 2018). Importantly, even excluding policy support for renewables, onshore wind and solar PVs have now attained lower LCOE values than traditional power generation technologies powered by coal or natural gas. To illustrate, in 2019 the LCOE of a potential new brown coal power plant, the cheapest fossil power source in Germany, ranged between $\$ \mathrm{c} 5.5 / \mathrm{kWh}$ and $\$ \mathrm{c} 9.6 / \mathrm{kWh}$ depending on the respective location (Kost et al. 2018$)$. In California, the LCOE of natural gas combinedcycle plants lies in the range of \$c5.8-8.0 per $\mathrm{kWh}$ in 2019 depending on the capacity utilization rate (Neff, 2019; Comello et al., 2020; Glenk and Reichelstein, 2021a).

\subsection{Levelized Cost of Hydrogen}

In direct analogy to the LCOE concept, we finally examine the dynamics of the life-cycle cost of hydrogen (LCOH) production, when hydrogen is produced through water electrolysis. The $\mathrm{LCOH}$ is defined as the critical dollar value per $\mathrm{kg}$ of hydrogen that allows an investor to break even in terms of discounted after-tax cash flows over the useful life of the electrolyzer (Glenk and Reichelstein, 2021b). Aside from the initial equipment cost, applicable fixed operating costs include maintenance and spare part replacements. In contrast to renewable energy generation, electrolysis requires significant variable processing costs due to the consumption of electricity.

In further contrast to wind and solar photovoltaic power, the capacity factor of electrolysis is determined endogenously rather than being given exogenously by the availability of the respective natural resource. For the electrolyzer to operate efficiently, the contribution margin of hydrogen, defined as the amount of hydrogen obtained per kWh less any ancillary expenses for iodized water, must at any given hour exceed the price of electricity at that

\footnotetext{
${ }^{20} \mathrm{~A}$ regression of global average system prices of wind turbines over the years 2010-2019 yields a learning curve of $83.9 \%\left(R^{2}=0.92\right)$.
} 
time. The contribution margin of hydrogen $(\$ / \mathrm{kg})$ thus varies over time and hinges on the price of electricity as well as the time-invariant conversion rate that determines the number of kilograms of hydrogen obtained from one kWh of electricity (Glenk and Reichelstein, 2020).

We examine the dynamics of the $\mathrm{LCOH}$ in the context of PEM electrolyzers deployed in Germany, where most of the demonstration projects have been built to date (IEA, 2019). Table 2 shows average values of the main cost parameters for PEM electrolysis facilities in the years 2010 and 2019 (further details are provided in the Appendix in Table A6). The system prices correspond to those reported in Figure 6. Fixed operating costs are estimated as a percentage of the system cost.

Table 2: Cost parameters for PEM Electrolysis

\begin{tabular}{lcc}
\hline & \multicolumn{2}{c}{ Germany } \\
in $2019 \$ \mathrm{US}$ & 2010 & 2019 \\
\hline System price $(\$ / \mathrm{kW})$ & 2,571 & 1,064 \\
Fixed operating cost $(\$ / \mathrm{kW})$ & 77.13 & 31.91 \\
Hydrogen conversion rate $(\mathrm{kg} / \mathrm{kWh})$ & 0.0166 & 0.0192 \\
Average electricity buying price $(\$ c / \mathrm{kWh})$ & 6.20 & 4.42 \\
Cost of capital $(\%)$ & 4.60 & 2.00 \\
Useful lifetime (years) & 25 & 25 \\
\hline
\end{tabular}

The conversion rates reported in Table 2 originate from interviews with industry experts and are assumed to have increased linearly between the years 2010-2019 (IEA, 2019; Glenk and Reichelstein, 2019). The cost of capital is taken to be the same as for wind energy in Germany because electrolyzers are frequently co-located with wind power plants. The electrolysis is assumed to rely on electricity from the wholesale power market. Electricity purchases for water electrolysis are exempt in Germany from most taxes and fees paid by other industrial customers (EEG, 2020). Our calculations rely on hourly electricity prices in the day-ahead wholesale market.

Invoking again Wright's concept of learning-by-doing, Figure 9 shows the trajectory of the (logarithm of) LCOH values for PEM electrolysis in Germany as a function of the (logarithm of) global cumulative installed capacity. We find that the LCOH values have fallen from about $\$ 6.04 / \mathrm{kg}$ in 2010 to $\$ 2.93 / \mathrm{kg}$ in 2019 . This decline yields an estimate of a $9.2 \%$ learning rate, similar to that of the system prices for PEM electrolyzers shown in Figure 6. This alignment of learning rates may seem counter-intuitive in light of the fact that 
the variable cost of hydrogen production corresponding to electricity, i.e., $w$ in equation (2), is significant, and our argument that the LCOE of renewable energy experienced learning rates of around $40 \%$ over the past decade. The explanation here is that our calculations in Figure 9 are based on wholesale market prices in Germany, yet these declined at a much slower rate than the LCOE of wind and solar PV.
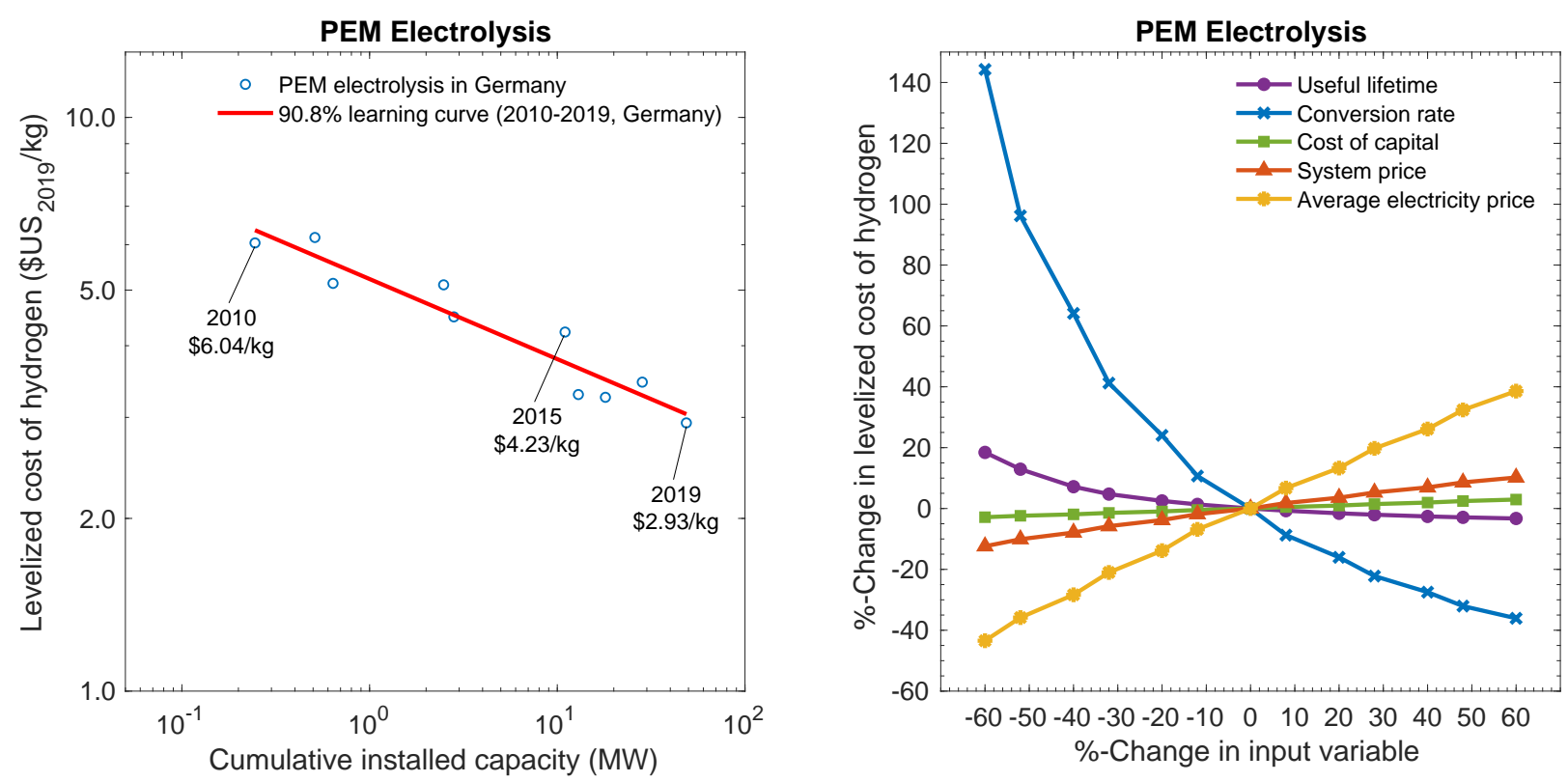

Figure 9: LCOH Dynamics and Sensitivity

Since the preceding calculations rely on several crucial parameter estimates, it is instructive to examine the sensitivity of the findings to changes in the key input variables. Figure 9 presents a sensitivity analysis in the form of a "spider diagram" based on cost and price parameters for the year 2019. The LCOH for PEM electrolysis is most sensitive to the conversion rate as this rate determines not only the amount of hydrogen obtained from $1 \mathrm{kWh}$ of electricity but, by implication, also the efficient capacity utilization rate, i.e., the capacity factor. As one might expect, the average electricity price is also a central driver of the $\mathrm{LCOH}$, reflecting that the price of electricity drives both the variable cost of hydrogen production and the resulting capacity factor. The relative insensitivity of the $\mathrm{LCOH}$ to changes in the cost of capital reflects that variable costs, rather than upfront investment, account for the majority of the life-cycle cost.

While our analysis focused on electrolysis facilities operating as stand-alone units, many 
electrolyzers currently deployed are co-located with a renewable energy source (IEA, 2019) ${ }^{21}$ Such vertical integration enables the transfer of renewable power to the electrolyzer and entails operational synergies whenever the price for buying electricity from the grid exceeds the selling price faced by the renewable source. As Glenk and Reichelstein (2020) show, such synergistic benefits can cause a vertically integrated electrolyzer to break even at a substantially lower price for hydrogen than a stand-alone electrolyzer feeding on grid electricity.

\section{Concluding Remarks}

It is widely acknowledged that the economics of carbon-free energy generation has improved substantially in recent years as these relatively new technologies have been deployed at an accelerating pace. Solar photovoltaic modules provide a prime example of a price trajectory for which the $80 \%$ constant elasticity learning curve has proven highly descriptive over the time period 1976-2008. While observers frequently voiced concern about the possibility of extending this rate of price reductions indefinitely, the past decade has seen price declines for solar PV modules at rates that are substantially faster than the traditional $20 \%$ rate. ${ }^{22}$

Our analysis in this paper has shown that the learning rates of the levelized cost of energy are, in some instances, substantially faster than those observed for the system prices of the underlying clean energy technology, i.e., wind turbines or solar PV systems. This finding primarily reflects a "denominator effect" in the calculation of the LCOE. Technological progress has not only lowered the cost of producing the power generation system, represented in the numerator of the LCOE, but also increased the capacity factor, represented in the denominator, due to better conversion rates for the available wind or solar resources.

From the perspective of the overall transition to a carbon-free energy system, we note that there are significant economic synergies between the technologies examined in this paper. For instance, the anticipated future learning effects for both renewable energy and lithium ion battery packs have a compounding effect in terms of the levelized cost per mile driven for battery electric vehicles (Comello et al., 2021). Similarly, as illustrated in Figure 10, the cost of green hydrogen obtained through electrolysis will be pushed down not only by lower electrolyzer prices but also by cheaper renewable energy feeding the electrolysis process.

\footnotetext{
${ }^{21}$ Wind power naturally complements electrolyzers as it produces most of its output during the night when demand from the grid and electricity prices are low (Reichelstein and Sahoo, 2015).

${ }^{22}$ This observation brings Mark Twain's well-known adage "...reports of my death are greatly exaggerated" to mind.
} 


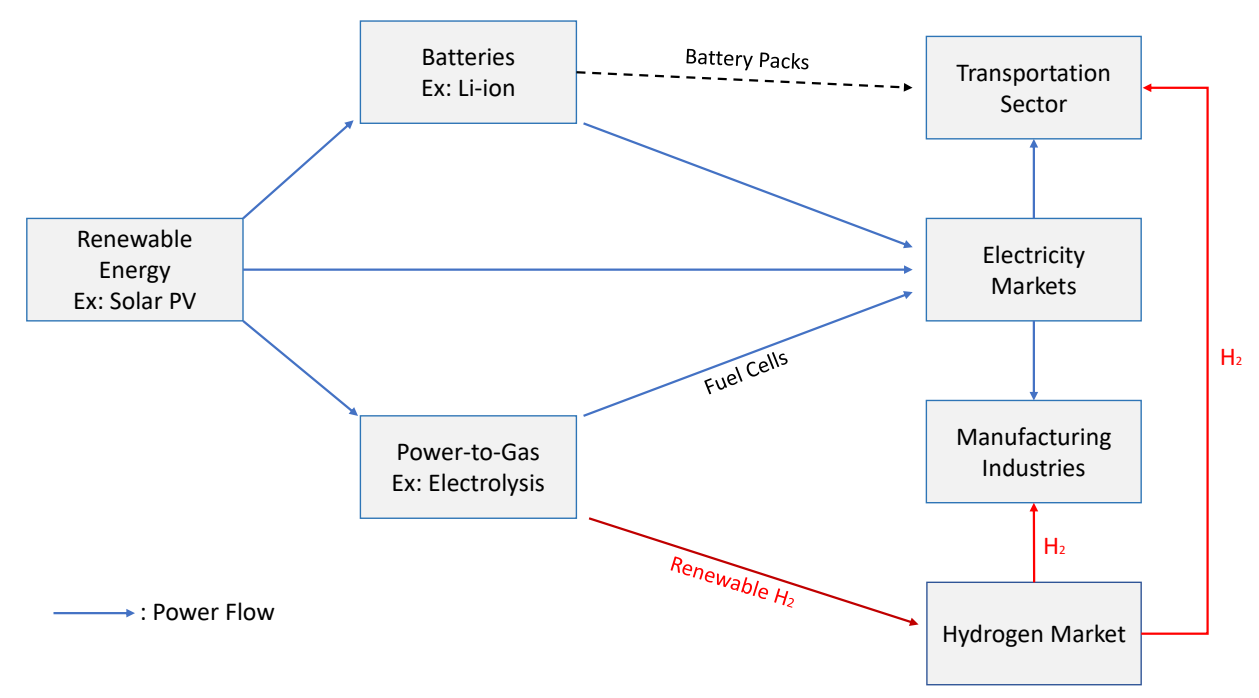

Figure 10: Interdependencies of Learning Effects

Moving further afield, inexpensive green hydrogen will make this energy carrier a potentially attractive alternative to coal as a heating agent in industries like cement and steel. Finally, low cost green hydrogen will make drivetrains powered by fuel cells more competitive with internal combustion engines and pure battery-electric vehicles.

One policy implication of our learning curve framework is that it allows for further quantification of how likely the attainment of certain cost reduction goals for clean energy is, and which public policies would enable the achievement of those goals by a specific target date. To illustrate, the Energy Secretary in the Biden administration, Jennifer Granholm, testified to Congress in April of 2021: "Over the coming weeks, we at the Department of Energy will be announcing new goals for bold, achievable leaps in next-generation technologies-starting with hydrogen, carbon capture, industrial fuels, and energy storage. We will marshal our National Labs, our universities, and our private sector to unlock major breakthroughs. So we've already announced a goal of cutting the price of solar in half yet again by 2030. And next, we'll start lowering the cost of clean, renewable hydrogen by 80 percent before 2030, making it competitive with natural gas."

Extrapolating the constant elasticity learning curve for the LCOE of solar PV systems in California, our estimates suggest that in order to reach the stated goal of cutting the cost of solar in half by 2030, cumulative global installation volume would have to double on average every 7.3 years. Too see this, we note that with a $60.4 \%$ learning curve Figure 7, cumulative 
global volume of solar PV installations would have to double in 7.3 years starting in 2020, and thereafter maintain that growth rate, because $\frac{2030-2020}{7.3}=1.37$ and $(0.602)^{1.37}=0.5$. Thus, global solar installations would have to double from the current $600 \mathrm{GW}$ to around 1,200 GW within the next 7.3 years and, on average, maintain that rate through 2030. By comparison, the average time to doubling for solar PV was only 3.9 years during the past decade.

The $80 \%$ cost cutting goal for hydrogen appears particularly ambitious. Referring to our learning curve estimate of $90.8 \%$ for electrolysis Figure 9 , cumulative global volume of electrolyzers would, on average, have to double every 0.6 years, because $\frac{2030-2020}{0.6}=16.68$ and $(0.908)^{16.68}=0.2$. In calibrating this required growth rate, it is useful to recall that between 2010 and 2019 the cumulative PEM electrolyzer capacity grew from 0.25 to $49 \mathrm{MW}$ Figure 9. That, in turn, corresponded to an average doubling time of 0.4 years.

The immediate follow-on question to these projections concerns the policy incentives that will have to be in place in order for the above deployment growth rates to be attained. As noted above, solar PV installations have taken off in response to investment tax credits, renewable energy portfolio standards and feed-in-tariffs. In contrast, for hydrogen no comparable support mechanism has been in place thus far in the U.S. or in Europe.

\section{Data availability}

The data used in this study are referenced in the main body of the paper and the Online Appendix. Additional data and information is available from the corresponding author upon reasonable request.

\section{Acknowledgments}

We gratefully acknowledge financial support through the Deutsche Forschungsgemeinschaft (DFG, German Research Foundation) - Project-ID 403041268 - TRR 266 and the Joachim Herz Stiftung. Helpful comments were provided by Stefanie Burgahn, Stephen Comello, Nikolas Wölfing, and colleagues at the University of Mannheim and Stanford University. We also thank Yadira Funk, Lucas Politycki, and Philipp Scherer for providing valuable assistance with data collection and processing. 


\section{Online Appendix}

\section{A Symbols and Acronyms}

$\begin{array}{ll}b & \text { Learning parameter } \\ \mathrm{BOS} & \text { Balance of system } \\ c & \text { Unit cost of capacity }(\$ / \mathrm{kWh}) \\ \mathrm{CO}_{2} & \text { Carbon dioxide } \\ { }^{\circ} \mathrm{C} & \text { Degree Celcius } \\ \Delta & \text { Tax factor }(-) \\ f & \text { Levelized fixed operating cost }(\$ / \mathrm{kWh}) \\ \mathrm{GW} & \text { Gigawatts } \\ \mathrm{IPCC} & \text { Intergovernmental Panel on Climate Change } \\ \mathrm{LCOE} & \text { Levelized cost of electricity }(\$ / \mathrm{kWh}) \\ \mathrm{LCOH} & \text { Levelized cost of hydrogen }(\$ / \mathrm{kg}) \\ \mathrm{kWh} & \text { Kilowatt hour } \\ \mathrm{MW} & \text { Megawatts } \\ \mathrm{MWh} & \text { Megawatt hours } \\ n & \text { Number of years } \\ P & \text { Sales price per unit of equipment } \\ \mathrm{PEM} & \text { Polymer electrolyte membrane } \\ \mathrm{PV} & \text { Photovoltaic } \\ Q & \text { Quantity of cumulative industry output } \\ T(\cdot) & \text { Number of transistors } \\ w & \text { Levelized variable operating cost }(\$ / \mathrm{kWh}) \\ \mathrm{W} & \text { Watt } \\ \mathrm{WACC} & \text { Weighted average cost of capital } \\ \mathrm{Wh} & \text { Watt hours }\end{array}$




\section{B Cost and Price Parameters}

Table A1 provides a comprehensive list of input parameters used for estimating the learning curves of system price components of all four clean energy technologies. The corresponding source for each data vector is provided in the last row of the table.

Table A1: Global system prices and cumulative installed capacity.

\begin{tabular}{|c|c|c|c|c|c|c|c|c|}
\hline \multirow[b]{2}{*}{ Year } & \multicolumn{2}{|c|}{ Solar PV } & \multicolumn{2}{|c|}{ Onshore Wind } & \multicolumn{2}{|c|}{ Li-ion Batteries } & \multicolumn{2}{|c|}{ PEM Electrolysis } \\
\hline & $\begin{array}{l}\text { Module Price } \\
(\$ / W)\end{array}$ & $\begin{array}{c}\text { Capacity } \\
(\mathrm{kW})\end{array}$ & $\begin{array}{c}\text { System Price } \\
(\$ / W)\end{array}$ & $\begin{array}{c}\text { Capacity } \\
(\mathrm{kW})\end{array}$ & $\begin{array}{l}\text { Pack Price } \\
(\$ / \mathrm{Wh})\end{array}$ & $\begin{array}{c}\text { Capacity } \\
(\mathrm{kW})\end{array}$ & $\begin{array}{c}\text { System Price } \\
(\$ / W)\end{array}$ & $\begin{array}{c}\text { Capacity } \\
(\mathrm{kW})\end{array}$ \\
\hline 1976 & 81,616 & 4 & - & - & - & - & - & - \\
\hline 1977 & 61,568 & 6 & - & - & - & - & - & - \\
\hline 1978 & 42,477 & 9 & - & _ & _ & - & _ & _- \\
\hline 1979 & 31,729 & 13 & - & - & - & - & - & - \\
\hline 1980 & 26,062 & 19 & - & - & _- & - & _ & - \\
\hline 1981 & 20,502 & 27 & - & - & - & - & - & - \\
\hline 1982 & 18,433 & 39 & - & - & - & - & - & - \\
\hline 1983 & 15,593 & 59 & 5,179 & 274 & - & - & - & - \\
\hline 1984 & 13,906 & 81 & 4,898 & 680 & - & - & - & - \\
\hline 1985 & 12,951 & 107 & 4,799 & 995 & - & - & - & - \\
\hline 1986 & 10,407 & 135 & 4,229 & 1,354 & - & - & - & - \\
\hline 1987 & 7,901 & 164 & 4,090 & 1,469 & - & - & - & - \\
\hline 1988 & 7,028 & 198 & 3,141 & 1,465 & - & - & - & - \\
\hline 1989 & 7,766 & 238 & 2,943 & 1,655 & - & - & - & - \\
\hline 1990 & 8,331 & 285 & 3,318 & 1,943 & - & - & - & - \\
\hline 1991 & 8,093 & 340 & 3,264 & 2,392 & - & - & - & - \\
\hline 1992 & 7,570 & 400 & 3,211 & 2,587 & - & - & - & - \\
\hline 1993 & 7,499 & 460 & 3,214 & 2,930 & - & - & - & - \\
\hline 1994 & 6,750 & 530 & 2,975 & 3,527 & - & - & - & - \\
\hline 1995 & 6,131 & 610 & 2,720 & 4,763 & - & - & - & - \\
\hline 1996 & 6,488 & 699 & 2,587 & 6,007 & - & - & - & - \\
\hline 1997 & 6,785 & 825 & 2,447 & 7,482 & - & - & - & - \\
\hline 1998 & 6,761 & 978 & 2,432 & 9,667 & - & - & - & - \\
\hline 1999 & 5,704 & 1,179 & 2,269 & 13,700 & - & - & - & - \\
\hline 2000 & 5,465 & 1,469 & 2,217 & 18,039 & - & - & - & - \\
\hline 2001 & 5,690 & 1,860 & 2,075 & 24,322 & - & - & - & - \\
\hline 2002 & 5,126 & 2,385 & 2,055 & 31,181 & - & - & - & - \\
\hline 2003 & 4,556 & 3,075 & 1,955 & 39,295 & - & - & - & - \\
\hline 2004 & 4,477 & 3,971 & 1,966 & 47,678 & - & - & 6,360 & 0.007 \\
\hline 2005 & 4,620 & 5,344 & 1,859 & 59,009 & - & - & 3,762 & 0.040 \\
\hline 2006 & 4,842 & 6,845 & 1,895 & 74,109 & - & - & 3,219 & 0.057 \\
\hline 2007 & 4,402 & 9,618 & 1,921 & 93,916 & - & - & 3,191 & 0.140 \\
\hline 2008 & 4,622 & 16,166 & 2,018 & 120,888 & - & - & 3,628 & 0.224 \\
\hline 2009 & 2,313 & 23,833 & 2,051 & 159,744 & - & - & 2,730 & 0.233 \\
\hline 2010 & 1,961 & 41,925 & 1,949 & 196,104 & 1,125 & 426 & 2,571 & 0.245 \\
\hline 2011 & 1,022 & 70,240 & 1,939 & 235,184 & 886 & 1,982 & 2,295 & 0.511 \\
\hline 2012 & 656 & 100,201 & 1,972 & 279,670 & 703 & 4,734 & 2,239 & 0.639 \\
\hline 2013 & 802 & 141,661 & 1,828 & 313,882 & 651 & 10,396 & 2,807 & 2.480 \\
\hline 2014 & 709 & 186,661 & 1,781 & 364,978 & 571 & 20,714 & 2,593 & 2.812 \\
\hline 2015 & 673 & 242,661 & 1,642 & 427,244 & 400 & 41,036 & 2,643 & 11.000 \\
\hline 2016 & 440 & 318,972 & 1,635 & 476,300 & 277 & 70,805 & 1,844 & 12.951 \\
\hline 2017 & 389 & 417,972 & 1,628 & 524,137 & 217 & 111,682 & 1,572 & 18.045 \\
\hline 2018 & 275 & 525,972 & 1,549 & 569,596 & 190 & 200,000 & 1,188 & 28.369 \\
\hline 2019 & 255 & 626,920 & 1,473 & 624,626 & 154 & 351,000 & 1,064 & 48.713 \\
\hline Sources & {$[1]$} & {$[1]$} & {$[2]$} & {$[2,3]$} & {$[4,5]$} & {$[1,6]$} & {$[7]$} & {$[8]$} \\
\hline
\end{tabular}


Tables A2 A5 provide a comprehensive list of annual input parameters and corresponding sources for our calculations of the LCOE of solar and wind energy in California and Germany. For solar PV and wind power facilities in California, system prices and fixed operating cost reflect average values of respective plants installed across the entire United States in the particular year, adjusted for the price level in California using averaged city cost indexes by RSMeans (2020). System prices for solar PV and wind turbines are taken from Bolinger et al. (2020) and Wiser et al. (2020), respectively. Fixed operating cost are calculated for either energy source from data by ABB (2020). Annual average capacity factors of solar PV and wind energy facilities in California are calculated based on reported hourly capacity factors of individual plants in a particular year as provided by ABB (2020).

For solar PV and wind power plants in Germany, system prices and fixed operating cost reflect average values of respective facilities in Germany in the particular year. System prices for solar PV and wind turbines are collected from IRENA 2020) as are fixed operating cost for wind power plants. Fixed operating cost for solar PV facilities are calculated from data by Steffen et al. (2020). Annual average capacity factors of solar PV and wind energy facilities in Germany are calculated based on reported average capacity factors of individual plants in a particular year as provided by BMWi (2020) and IRENA (2020) for solar and wind, respectively.

Table A2: Levelized cost dynamics for solar PV in California.

\begin{tabular}{|c|c|c|c|c|c|c|c|c|c|c|c|}
\hline in $2019 \$ \mathrm{US}$ & Source & 2010 & 2011 & 2012 & 2013 & 2014 & 2015 & 2016 & 2017 & 2018 & 2019 \\
\hline \multicolumn{12}{|l|}{ Input Parameters } \\
\hline Useful lifetime (years) & {$[1]$} & 30 & 30 & 30 & 30 & 30 & 30 & 30 & 30 & 30 & 30 \\
\hline System price $(\$ / \mathrm{kW})$ & {$[9]$} & 5,396 & 4,485 & 4,088 & 3,504 & 2,967 & 2,593 & 2,161 & 1,986 & 1,565 & 1,343 \\
\hline Fixed operating cost $(\$ / \mathrm{kW})$ & [2] & 14.03 & 12.21 & 12.39 & 12.90 & 11.28 & 9.15 & 6.92 & 6.79 & 8.27 & 8.81 \\
\hline Variable operating cost $(\$ c / \mathrm{kWh})$ & & 0.00 & 0.00 & 0.00 & 0.00 & 0.00 & 0.00 & 0.00 & 0.00 & 0.00 & 0.00 \\
\hline Capacity utilization rate $(\%)$ & {$[2]$} & 21.04 & 21.04 & 20.83 & 21.78 & 26.75 & 27.67 & 27.67 & 29.23 & 29.59 & 28.69 \\
\hline Cost of capital $(\%)$ & {$[3,10]$} & 6.04 & 5.78 & 5.47 & 5.46 & 5.25 & 4.92 & 4.68 & 4.80 & 5.15 & 4.50 \\
\hline Degradation factor (\%) & {$[1,4,5]$} & 99.50 & 99.50 & 99.50 & 99.50 & 99.50 & 99.50 & 99.50 & 99.50 & 99.50 & 99.50 \\
\hline Investment tax credit (\%) & & 0.00 & 0.00 & 0.00 & 0.00 & 0.00 & 0.00 & 0.00 & 0.00 & 0.00 & 0.00 \\
\hline ITC capitalization $(\%)$ & & 50.00 & 50.00 & 50.00 & 50.00 & 50.00 & 50.00 & 50.00 & 50.00 & 50.00 & 50.00 \\
\hline Production tax credit $(\$ c / k W h)$ & & 0.00 & 0.00 & 0.00 & 0.00 & 0.00 & 0.00 & 0.00 & 0.00 & 0.00 & 0.00 \\
\hline State tax rate $(\%)$ & {$[6]$} & 8.84 & 8.84 & 8.84 & 8.84 & 8.84 & 8.84 & 8.84 & 8.84 & 8.84 & 8.84 \\
\hline Federal tax rate $(\%)$ & {$[7]$} & 35.00 & 35.00 & 35.00 & 35.00 & 35.00 & 35.00 & 35.00 & 35.00 & 21.00 & 21.00 \\
\hline State tax depreciation method $(-)^{*}$ & {$[8]$} & 3 & 3 & 3 & 3 & 3 & 3 & 3 & 3 & 3 & 3 \\
\hline Federal tax depreciation method $(-)^{*}$ & {$[8]$} & 2 & 2 & 2 & 2 & 2 & 2 & 2 & 2 & 5 & 5 \\
\hline \multicolumn{12}{|l|}{ Levelized Cost } \\
\hline Cost of capacity, $c(\$ c / k W h)$ & & 22.47 & 18.18 & 16.20 & 13.26 & 8.94 & 7.28 & 5.91 & 5.21 & 4.22 & 3.47 \\
\hline Tax factor, $\Delta(-)$ & & 1.13 & 1.12 & 1.12 & 1.12 & 1.11 & 1.11 & 1.10 & 1.10 & 1.03 & 1.03 \\
\hline Fixed operating cost, $f(\$ \mathrm{c} / \mathrm{kWh})$ & & 0.80 & 0.70 & 0.72 & 0.71 & 0.51 & 0.40 & 0.30 & 0.28 & 0.34 & 0.37 \\
\hline Variable operating cost, $w(\$ c / \mathrm{kWh})$ & & 0.00 & 0.00 & 0.00 & 0.00 & 0.00 & 0.00 & 0.00 & 0.00 & 0.00 & 0.00 \\
\hline $\mathrm{LCOE}(\$ \mathrm{c} / \mathrm{kWh})$ & & 26.10 & 21.08 & 18.80 & 15.51 & 10.45 & 8.46 & 6.81 & 6.03 & 4.70 & 3.95 \\
\hline
\end{tabular}


Table A3: Levelized cost dynamics for onshore wind in California.

\begin{tabular}{|c|c|c|c|c|c|c|c|c|c|c|c|}
\hline in $2019 \$$ US & Source & 2010 & 2011 & 2012 & 2013 & 2014 & 2015 & 2016 & 2017 & 2018 & 2019 \\
\hline \multicolumn{12}{|l|}{ Input Parameters } \\
\hline Useful lifetime (years) & {$[1]$} & 30 & 30 & 30 & 30 & 30 & 30 & 30 & 30 & 30 & 30 \\
\hline System price $(\$ / \mathrm{kW})$ & [10] & 2,927 & 2,805 & 2,532 & 2,382 & 2,198 & 2,000 & 2,044 & 1,959 & 1,747 & 1,678 \\
\hline Fixed operating cost $(\$ / \mathrm{kW})$ & {$[2]$} & 28.75 & 32.94 & 21.30 & 25.27 & 22.10 & 20.04 & 24.35 & 25.76 & 23.07 & 21.94 \\
\hline Variable operating cost $(\$ c / k W h)$ & & 0.00 & 0.00 & 0.00 & 0.00 & 0.00 & 0.00 & 0.00 & 0.00 & 0.00 & 0.00 \\
\hline Capacity utilization rate $(\%)$ & {$[2]$} & 27.84 & 34.05 & 32.13 & 34.25 & 31.62 & 30.99 & 33.69 & 32.44 & 37.74 & 34.70 \\
\hline Cost of capital (\%) & {$[3,10]$} & 6.04 & 5.78 & 5.47 & 5.46 & 5.25 & 4.92 & 4.68 & 4.80 & 5.15 & 4.50 \\
\hline Degradation factor (\%) & {$[5,10]$} & 99.20 & 99.20 & 99.20 & 99.20 & 99.20 & 99.20 & 99.20 & 99.20 & 99.20 & 99.20 \\
\hline Investment tax credit (\%) & {$[7]$} & 0.00 & 0.00 & 0.00 & 0.00 & 0.00 & 0.00 & 0.00 & 0.00 & 0.00 & 0.00 \\
\hline ITC capitalization $(\%)$ & [1] & 50.00 & 50.00 & 50.00 & 50.00 & 50.00 & 50.00 & 50.00 & 50.00 & 50.00 & 50.00 \\
\hline Production tax credit $(\$ c / \mathrm{kWh})$ & & 0.00 & 0.00 & 0.00 & 0.00 & 0.00 & 0.00 & 0.00 & 0.00 & 0.00 & 0.00 \\
\hline State tax rate $(\%)$ & [6] & 8.84 & 8.84 & 8.84 & 8.84 & 8.84 & 8.84 & 8.84 & 8.84 & 8.84 & 8.84 \\
\hline Federal tax rate $(\%)$ & [7] & 35.00 & 35.00 & 35.00 & 35.00 & 35.00 & 35.00 & 35.00 & 35.00 & 21.00 & 21.00 \\
\hline State tax depreciation method $(-)^{*}$ & {$[8]$} & 3 & 3 & 3 & 3 & 3 & 3 & 3 & 3 & 3 & 3 \\
\hline Federal tax depreciation method $(-)^{*}$ & [8] & 2 & 2 & 2 & 2 & 2 & 2 & 2 & 2 & 5 & 5 \\
\hline \multicolumn{12}{|l|}{ Levelized Cost } \\
\hline Cost of capacity, $c(\$ \dot{c} / \mathrm{kWh})$ & & 9.49 & 7.24 & 6.71 & 5.91 & 5.78 & 5.18 & 4.74 & 4.78 & 3.81 & 3.70 \\
\hline Tax factor, $\Delta(-)$ & & 1.13 & 1.12 & 1.12 & 1.12 & 1.11 & 1.11 & 1.10 & 1.10 & 1.03 & 1.03 \\
\hline Fixed operating cost, $f(\$ c / k W h)$ & & 1.28 & 1.20 & 0.82 & 0.92 & 0.87 & 0.80 & 0.90 & 0.99 & 0.76 & 0.79 \\
\hline Variable operating cost, $w(\$ c / \mathrm{kWh})$ & & 2.04 & 2.03 & 2.04 & 2.08 & 2.05 & 2.05 & 2.05 & 1.67 & 1.07 & 0.70 \\
\hline $\mathrm{LCOE}(\$ \mathrm{c} / \mathrm{kWh})$ & & 11.96 & 9.32 & 8.31 & 7.51 & 7.29 & 6.53 & 6.12 & 6.27 & 4.70 & 4.61 \\
\hline
\end{tabular}

${ }^{*}$ 2: 5 year MACRS DDB depreciation, 3: 20 year 150\%-declining balance depreciation, 5: 100\% bonus depreciation.

[1] Comello et al. (2020), [2] ABB (2020), [3] Steffen (2020), [4] Jordan et al. (2012), [5] Wiser and Bolinger (2016), [6] Tax Foundation (2020), [7] Tax Foundation (2012), [8] U.S. IRS (2019), [9] Bolinger et al. (2020), [10] Wiser et al. (2020).

Table A4: Levelized cost dynamics for solar PV in Germany.

\begin{tabular}{|c|c|c|c|c|c|c|c|c|c|c|c|}
\hline in 2019 \$US & Source & 2010 & 2011 & 2012 & 2013 & 2014 & 2015 & 2016 & 2017 & 2018 & 2019 \\
\hline \multicolumn{12}{|l|}{ Input Parameters } \\
\hline Useful lifetime (years) & [1] & 30 & 30 & 30 & 30 & 30 & 30 & 30 & 30 & 30 & 30 \\
\hline System price $(\$ / \mathrm{kW})$ & {$[2]$} & 3,705 & 2,959 & 2,341 & 2,007 & 1,600 & 1,280 & 1,162 & 1,114 & 1,113 & 899 \\
\hline Fixed operating cost $(\$ / \mathrm{kW})$ & {$[3]$} & 35.51 & 31.60 & 27.69 & 23.79 & 19.88 & 15.97 & 12.06 & 8.15 & 7.73 & 7.34 \\
\hline Variable operating cost $(\$ \mathrm{c} / \mathrm{kWh})$ & & 0.00 & 0.00 & 0.00 & 0.00 & 0.00 & 0.00 & 0.00 & 0.00 & 0.00 & 0.00 \\
\hline Capacity utilization rate $(\%)$ & [4] & 7.44 & 8.63 & 8.84 & 9.64 & 10.86 & 11.27 & 10.69 & 10.63 & 11.57 & 10.80 \\
\hline Cost of capital (\%) & [5] & 4.60 & 4.15 & 3.70 & 4.20 & 3.68 & 3.15 & 2.63 & 2.42 & 2.21 & 2.00 \\
\hline Degradation factor (\%) & {$[1,6,7]$} & 99.50 & 99.50 & 99.50 & 99.50 & 99.50 & 99.50 & 99.50 & 99.50 & 99.50 & 99.50 \\
\hline Federal tax rate $(\%)$ & & 30.00 & 30.00 & 30.00 & 30.00 & 30.00 & 30.00 & 30.00 & 30.00 & 30.00 & 30.00 \\
\hline $\begin{array}{l}\text { Federal tax depreciation method }(-)^{*} \\
\text { Levelized Cost }\end{array}$ & [8] & 1 & 1 & 1 & 1 & 1 & 1 & 1 & 1 & 1 & 1 \\
\hline Cost of capacity, $c(\$ c / k W h)$ & & 37.34 & 24.39 & 17.87 & 14.90 & 9.91 & 7.16 & 6.41 & 6.02 & 5.38 & 4.52 \\
\hline Tax factor, $\Delta(-)$ & & 1.15 & 1.14 & 1.13 & 1.14 & 1.13 & 1.11 & 1.10 & 1.09 & 1.09 & 1.08 \\
\hline Fixed operating cost, $f(\$ \mathrm{c} / \mathrm{kWh})$ & & 5.76 & 4.42 & 3.79 & 2.98 & 2.22 & 1.72 & 1.37 & 0.93 & 0.81 & 0.83 \\
\hline Variable operating cost, $w(\$ c / k W h)$ & & 0.00 & 0.00 & 0.00 & 0.00 & 0.00 & 0.00 & 0.00 & 0.00 & 0.00 & 0.00 \\
\hline $\mathrm{LCOE}(\$ \mathrm{c} / \mathrm{kWh})$ & & 48.79 & 32.26 & 23.98 & 20.00 & 13.40 & 9.70 & 8.41 & 7.50 & 6.65 & 5.70 \\
\hline
\end{tabular}

*1: 20 year linear depreciation schedule, 2: 16 year linear depreciation schedule.

[1] Comello et al. (2020), [2] IRENA (2020), [3] Steffen et al. (2020), [4] BMWi (2020), [5] Steffen (2020), [6] Jordan et al. (2012), [7] Wiser and Bolinger (2016), [8] BMF (2000). 
Table A5: Levelized cost dynamics for onshore wind in Germany.

\begin{tabular}{|c|c|c|c|c|c|c|c|c|c|c|c|}
\hline in $2019 \$$ US & Source & 2010 & 2011 & 2012 & 2013 & 2014 & 2015 & 2016 & 2017 & 2018 & 2019 \\
\hline \multicolumn{12}{|l|}{ Input Parameters } \\
\hline Useful lifetime (years) & {$[1]$} & 30 & 30 & 30 & 30 & 30 & 30 & 30 & 30 & 30 & 30 \\
\hline System price $(\$ / \mathrm{kW})$ & {$[2]$} & 2,271 & 2,271 & 2,063 & 2,038 & 2,011 & 1,973 & 1,936 & 1,935 & 1,904 & 1,762 \\
\hline Fixed operating cost $(\$ / \mathrm{kW})$ & {$[2]$} & 73.00 & 73.00 & 68.00 & 68.00 & 64.00 & 64.00 & 56.00 & 53.63 & 51.25 & 48.88 \\
\hline Variable operating cost $(\$ c / k W h)$ & & 0.00 & 0.00 & 0.00 & 0.00 & 0.00 & 0.00 & 0.00 & 0.00 & 0.00 & 0.00 \\
\hline Capacity utilization rate (\%) & {$[2]$} & 24.00 & 24.00 & 24.00 & 24.10 & 25.30 & 26.10 & 26.90 & 27.10 & 31.30 & 31.10 \\
\hline Cost of capital (\%) & [3] & 4.60 & 4.70 & 3.90 & 3.90 & 4.00 & 3.30 & 2.70 & 2.47 & 2.23 & 2.00 \\
\hline Degradation factor (\%) & {$[1,4,5]$} & 99.50 & 99.50 & 99.50 & 99.50 & 99.50 & 99.50 & 99.50 & 99.50 & 99.50 & 99.50 \\
\hline Federal tax rate $(\%)$ & & 30.00 & 30.00 & 30.00 & 30.00 & 30.00 & 30.00 & 30.00 & 30.00 & 30.00 & 30.00 \\
\hline $\begin{array}{l}\text { Federal tax depreciation method }(-)^{*} \\
\text { Levelized Cost }\end{array}$ & \multicolumn{10}{|c|}{ Levelized Cost } & 2 \\
\hline Cost of capacity, $c(\$ c / k W h)$ & & 7.09 & 7.17 & 5.94 & 5.84 & 5.56 & 4.86 & 4.29 & 4.13 & 3.41 & 3.08 \\
\hline Tax factor, $\Delta(-)$ & & 1.13 & 1.13 & 1.11 & 1.11 & 1.12 & 1.10 & 1.08 & 1.08 & 1.07 & 1.06 \\
\hline Fixed operating cost, $f(\$ c / \mathrm{kWh})$ & & 3.67 & 3.67 & 3.43 & 3.41 & 3.06 & 2.97 & 2.53 & 2.41 & 1.99 & 1.91 \\
\hline Variable operating cost, $w(\$ c / k W h)$ & & 0.00 & 0.00 & 0.00 & 0.00 & 0.00 & 0.00 & 0.00 & 0.00 & 0.00 & 0.00 \\
\hline $\mathrm{LCOE}(\$ \mathrm{c} / \mathrm{kWh})$ & & 11.68 & 11.79 & 10.04 & 9.92 & 9.26 & 8.31 & 7.18 & 6.85 & 5.65 & 5.19 \\
\hline
\end{tabular}

Table A6: Levelized cost dynamics for PEM electrolysis in Germany.

\begin{tabular}{|c|c|c|c|c|c|c|c|c|c|c|c|}
\hline in $2019 \$$ US & Source & 2010 & 2011 & 2012 & 2013 & 2014 & 2015 & 2016 & 2017 & 2018 & 2019 \\
\hline \multicolumn{12}{|l|}{ Input Parameters } \\
\hline Useful lifetime (years) & [1] & 25 & 25 & 25 & 25 & 25 & 25 & 25 & 25 & 25 & 25 \\
\hline System price $(\$ / \mathrm{kW})$ & {$[1]$} & 2,571 & 2,295 & 2,239 & 2,807 & 2,593 & 2,643 & 1,844 & 1,572 & 1,188 & 1,064 \\
\hline Fixed operating cost $(\$ / \mathrm{kW})$ & {$[1]$} & 77.13 & 68.86 & 67.18 & 84.22 & 77.78 & 79.30 & 55.32 & 47.17 & 35.64 & 31.91 \\
\hline Variable operating cost $(\$ / \mathrm{kg})$ & [1] & 0.0019 & 0.0019 & 0.0019 & 0.0020 & 0.0020 & 0.0020 & 0.0021 & 0.0021 & 0.0021 & 0.0022 \\
\hline Conv. rate to hydrogen $(\mathrm{kg} / \mathrm{kWh})$ & {$[1,2]$} & 0.0166 & 0.0169 & 0.0172 & 0.0174 & 0.0177 & 0.0180 & 0.0183 & 0.0186 & 0.0189 & 0.0192 \\
\hline Avg. electr. buying price $(\$ \mathrm{c} / \mathrm{kWh})$ & & 6.20 & 6.95 & 5.72 & 5.00 & 4.28 & 4.06 & 3.66 & 4.20 & 5.29 & 4.42 \\
\hline Opt. capacity utilization rate $(\%)$ & & 97.20 & 98.72 & 95.00 & 96.31 & 97.97 & 98.49 & 93.50 & 88.70 & 72.51 & 75.84 \\
\hline Cost of capital (\%) & [3] & 4.60 & 4.70 & 3.90 & 3.90 & 4.00 & 3.30 & 2.70 & 2.47 & 2.23 & 2.00 \\
\hline Degradation factor (\%) & [4] & 98.40 & 98.40 & 98.40 & 98.40 & 98.40 & 98.40 & 98.40 & 98.40 & 98.40 & 98.40 \\
\hline Federal tax rate $(\%)$ & & 30.00 & 30.00 & 30.00 & 30.00 & 30.00 & 30.00 & 30.00 & 30.00 & 30.00 & 30.00 \\
\hline Federal tax depreciation method $(-)^{*}$ & [5] & 2 & 2 & 2 & 2 & 2 & 2 & 2 & 2 & 2 & 2 \\
\hline \multicolumn{12}{|l|}{ Levelized Cost } \\
\hline Cost of capacity, $c(\$ / \mathrm{kg})$ & & 1.44 & 1.26 & 1.16 & 1.41 & 1.27 & 1.18 & 0.80 & 0.69 & 0.62 & 0.51 \\
\hline Tax factor, $\Delta(-)$ & & 1.13 & 1.13 & 1.11 & 1.11 & 1.12 & 1.10 & 1.08 & 1.08 & 1.07 & 1.06 \\
\hline Fixed operating cost, $f(\$ / \mathrm{kg})$ & & 0.64 & 0.55 & 0.55 & 0.67 & 0.60 & 0.60 & 0.43 & 0.38 & 0.35 & 0.30 \\
\hline Variable operating cost, $w(\$ / \mathrm{kg})$ & & 3.77 & 4.20 & 3.30 & 2.87 & 2.47 & 2.33 & 1.99 & 2.12 & 2.45 & 2.10 \\
\hline $\mathrm{LCOH}(\$ / \mathrm{kg})$ & & 6.04 & 6.18 & 5.14 & 5.11 & 4.49 & 4.23 & 3.29 & 3.25 & 3.46 & 2.93 \\
\hline
\end{tabular}

*1: 20 year linear depreciation schedule, 2: 16 year linear depreciation schedule.

[1] Glenk and Reichelstein (2020), [2] IEA (2019), [3] Steffen (2020), [4] Buttler and Spliethoff (2018), [5] BMF (2000).

\section{References}

ABB. Velocity Suite - Market Intelligence Services, 2020.

Felix Baumgarte, Gunther Glenk, and Alexander Rieger. Business Models and Profitability of Energy Storage. iScience, 23(10):101554, 2020. ISSN 25890042. doi: 10.1016/j.isci.2020.101554.

BMF. AfA-Tabelle für die allgemein verwendbaren Anlagegüter ("AV"), December 2000. URL https://www.bundesfinanzministerium.de/Content/DE/Standardartikel/ 
BMWi. Time series for the development od renewable energy sources in Germany. Technical report, Federal Ministry for Economic Affairs and Energy, August 2020.

BNEF. Long-Term Electric Vehicle Outlook 2019. Technical report, BloombergNEF, 2019a.

BNEF. New Energy Outlook 2019. Technical report, BloombergNEF, 2019b.

BNEF. 2020 Lithium-Ion Battery Price Survey. Technical report, BloombergNEF, 2020.

Mark Bolinger and Ryan Wiser. Understanding wind turbine price trends in the us over the past decade. Energy Policy, 42:628-641, 2012.

Mark Bolinger, Joachim Seel, Dana Robson, and Cody Warner. Utility-Scale Solar. Technical report, Berkeley Lab, 2020.

Alexander Buttler and Hartmut Spliethoff. Current status of water electrolysis for energy storage, grid balancing and sector coupling via power-to-gas and power-to-liquids: A review. Renewable and Sustainable Energy Reviews, 82(February):2440-2454, 2018. ISSN 18790690. doi: 10.1016/ j.rser.2017.09.003.

Stephen Comello and Stefan Reichelstein. The emergence of cost effective battery storage. Nature Communications, 10(1):2038, 2019. ISSN 2041-1723. doi: 10.1038/s41467-019-09988-z.

Stephen Comello, Gunther Glenk, and Stefan Reichelstein. Levelized Cost of Electricity Calculator, 2020. URL https://tinyurl.com/yb5aac92.

Stephen Comello, Gunther Glenk, and Stefan Reichelstein. Transitioning to clean energy transportation services : Life-cycle cost analysis for vehicle fleets. Applied Energy, 285(December 2020):116408, 2021. ISSN 0306-2619. doi: 10.1016/j.apenergy.2020.116408.

Stephen D Comello, Gunther Glenk, and Stefan Reichelstein. Levelized Cost of Electricity Calculator, 2017.

Claire Curry. Lithium-ion Battery Costs and Market. Technical report, Bloomberg New Energy Finance, 2017.

Steven J Davis, Nathan S Lewis, Matthew Shaner, Sonia Aggarwal, Doug Arent, Inês L Azevedo, Sally M Benson, Thomas Bradley, Jack Brouwer, Yet-Ming Chiang, Christopher T M Clack, Armond Cohen, Stephen Doig, Jae Edmonds, Paul Fennell, Christopher B Field, Bryan Hannegan, Bri-Mathias Hodge, Martin I Hoffert, Eric Ingersoll, Paulina Jaramillo, Klaus S Lackner, Katharine J Mach, Michael Mastrandrea, Joan Ogden, F Peterson, Daniel L Sanchez, Daniel 
Sperling, Joseph Stagner, Jessika E Trancik, Chi-Jen Yang, and Ken Caldeira. Net-zero emissions energy systems. Science, 9793(June), 2018. ISSN 0036-8075. doi: 10.1126/science.aas9793.

EEG. Gesetz für den Ausbau Erneuerbarer Energien -ErneuerbareEnergien-Gesetz - EEG 2021, 2020. URL http://www.gesetze-im-internet.de/eeg_2014/EEG_2021.pdf.

EERE. Infrastructure and Logistical Challenges, 2020. URL https://www.energy.gov/eere/ wind/infrastructure-and-logistics.

Asari Efiong and Andrew Crispin. Wind Turbine Manufacturers; Here Comes Pricing Power. Merrill Lynch Industry Overview, August 2007.

Florian Egli, Bjarne Steffen, and Tobias S. Schmidt. A dynamic analysis of financing conditions for renewable energy technologies. Nature Energy, 3(12):1084-1092, 2018. ISSN 20587546. doi: 10.1038/s41560-018-0277-y.

Bill Gates. How to Avoid a Climate Disaster: The Solutions We Have and the Breakthroughs We Need. Knopf, 2021.

GE. 2019 Annual Report. Technical report, General Electric Company, 2019. URL https: //www.ge.com/sites/default/files/GE_AR19_AnnualReport.pdf.

G. Glenk and S. Reichelstein. Renewable versus Traditional Power Generation: The State of the Race. Working Paper, 2021a.

Gunther Glenk and Stefan Reichelstein. Economics of Converting Renewable Power to Hydrogen. Nature Energy, 4:216-222, 2019. ISSN 2058-7546. doi: 10.1038/s41560-019-0326-1.

Gunther Glenk and Stefan Reichelstein. Synergistic Value in Vertically Integrated Power-to-Gas Energy Systems. Production and Operations Management, 29(3):526-546, 2020. ISSN 19375956. doi: 10.1111/poms.13116.

Gunther Glenk and Stefan Reichelstein. Energy Conversion and Storage: The Value of Reversible Power-to-Gas Systems. Working Paper, 2021b.

Goldwind. Annual Report 2017. Technical report, Xinjiang Goldwind Science and Technology Co., LTD., 2017.

GWEC. Global Wind Report 2019. Global Wind Energy Council, 2019. URL https://gwec.net/ global-wind-report-2019/. [AccessedMarch08, 2020].

Daisuke Hayashi, Joern Huenteler, and Joanna I. Lewis. Gone with the wind: A learning curve analysis of China's wind power industry. Energy Policy, 120:38-51, 2018. 
Caroline Hayes. Jensen Huang: Moore's Law is Dead - Long live AI. Electronics Weekly, October 2018. URL https://www.electronicsweekly.com/news/products/micros/ jensen-huang-moores-law-dead-long-live-ai-2018-10/.

Heiner H. Heimes, Achim Kampker, Christoph Lienemann, Marc Locke, Christian Offermanns, Sarah Michaelis, and Ehsan Rahimzei. Lithium-ion battery cell production process. Technical report, PEM, VDMA, 2018.

Karin Ibenholt. Explaining learning curves for wind power. Energy policy, 30(13):1181-1189, 2002.

IEA. The Future of Hydrogen. Technical report, IEA, 2019.

IEA. Global EV Outlook 2020. Technical report, International Energy Agency, 2020a.

IEA. Renewables 2020. Technical report, IEA, Paris, 2020b. URL https://www .iea.org/reports/ renewables-2020

IRENA. Renewable power generation cost in 2019. Technical report, International Renewable Energy Agency, 2020.

Stephane Isoard and Antonio Soria. Technical change dynamics: evidence from the emerging renewable energy technologies. Energy Economics, 23(6):619-636, 2001.

Tooraj Jamasb. Technical change theory and learning curves: patterns of progress in electricity generation technologies. The Energy Journal, 28(3), 2007.

D C Jordan, J H Wohlgemuth, and S R Kurtz. Technology and climate trends in PV module degradation. 27th European Photovoltaic Solar Energy Conference and Exhibition, pages 31183124, 2012. doi: 10.4229/27thEUPVSEC2012-4DO.5.1.

Dirk C. Jordan and Sarah R. Kurtz. Photovoltaic degradation rates - an analytical review. Progress in photovoltaics: Research and Applications, 21(1):12-29, 2013.

Martin Junginger, Andre Faaij, and Wilhelmus C. Turkenburg. Global experience curves for wind farms. Energy policy, 33(2):133-150, 2005.

Goksin Kavlak, James McNerney, and Jessika E Trancik. Evaluating the causes of cost reduction in photovoltaic modules. Energy policy, 123:700-710, 2018.

Noah Kittner, Felix Lill, and Daniel M. Kammen. Energy storage deployment and innovation for the clean energy transition. Nature Energy, 2(9):1-6, 2017. ISSN 20587546. doi: 10.1038/ nenergy.2017.125.

Christoph Kost and Thomas Schlegl. Studie stromgestehungskosten erneuerbare energien. Technical report, Fraunhofer Institut für Solare Energiesysteme ISE, 2010. 
Christoph Kost, Shivenes Shammugam, Huyen-Tran Nguyen, and Thomas Schlegl. Stromgestehungskosten Erneuerbare Energien. Technical report, Fraunhofer ISE, 2018.

Lazard. Lazard's levelized cost of storage analysis - Version 2.0. Technical report, Lazard, 2016. URL https://www.lazard.com/media/438042/lazard-levelized-cost-of-storage-v20.pdf

Lazard. Lazard's levelized cost of storage analysis - Version 12.0. Technical report, Lazard, 2018.

Lazard. Lazard's Levelized Cost of Energy Analysis - Version 14.0. Technical report, Lazard, 2020.

Corinne Le Quéré, Robert B. Jackson, Matthew W. Jones, Adam JP. Smith, Sam Abernethy, Robbie M. Andrew, Anthony J. De-Gol, David R. Willis, Yuli Shan, Josep G. Canadell, et al. Temporary reduction in daily global CO 2 emissions during the COVID-19 forced confinement. Nature Climate Change, 10(7):647-653, 2020.

Marvin B Lieberman. The learning curve and pricing in the chemical processing industries. The RAND Journal of Economics, 15(2):213-228, 1984.

Johan Lilliestam, Marc Melliger, Lana Ollier, Tobias S Schmidt, and Bjarne Steffen. Understanding and accounting for the effect of exchange rate fluctuations on global learning rates. Nature energy, $5(1): 71-78,2020$.

Åsa Lindman and Patrik Söderholm. Wind power learning rates: A conceptual review and metaanalysis. Energy Economics, 34(3):754-761, 2012.

Atse Louwen and Wilfried van Sark. Technological Learning in the Transition to a Low-Carbon Energy System, chapter Photovoltaic solar engery, pages 65-86. Academic Press, 2020.

Lux Research. Turning lemons into lemonde: Opportunities in the turbulent pv equipment market. available by subscription to lux research. Technical report, Lux Research, 2012.

Asami Miketa and Leo Schrattenholzer. Experiments with a methodology to model the role of r\&d expenditures in energy technology learning processes; first results. Energy Policy, 32(15): 1679-1692, 2004.

MIT. The Future of Coal: Options for a Carbon-Constrained World. Technical report, MIT, 2007.

Tesla Motors. Gigafactory. Online, February 2014. URL https://www.tesla.com/en_PR/blog/ gigafactory.

Bryan Neff. Estimated Cost of New Utility-Scale Generation in California: 2018 Update. Technical report, California Energy Commission, May 2019. URL https://ww2.energy.ca.gov/ 2019publications/CEC-200-2019-005/CEC-200-2019-005.pdf 
Lena Neij. Cost development of future technologies for power generation-A study based on experience curves and complementary bottom-up assessments. Energy policy, 36(6):2200-2211, 2008.

Gregory F. Nemet. Interim monitoring of cost dynamics for publicly supported energy technologies. Energy Policy, 37(3):825-835, 2009.

NREL. Lifecycle Cost Analysis of Hydrogen Versus Other Technologies for Electrical Energy Storage. Technical Report NREL/TP-560-46719, pages 1-59, November 2009.

Jon Olauson, Nasir Ayob, Mikael Bergkvist, Nicole Carpman, Valeria Castellucci, Anders Goude, David Lingfors, Rafael Waters, and Joakim Widén. Net load variability in the Nordic countries with a highly or fully renewable power system. Nature Energy, 1(December):1-14, nov 2016. ISSN 2058-7546. doi: 10.1038/nenergy.2016.175.

Jean Pitteloud. Global Wind Power Statistics. Online, February 2019. URL https:// public.tableau.com/profile/jean.pitteloud\#!/vizhome/shared/BC4YP2J3H. Accessed online 21.01.2021.

Michael E. Porter. The Competitive Advantage Of Nations. Free Press, 1990.

Lee E Preston and Edward C Keachie. Cost functions and progress functions: An integration. The American Economic Review, 54(2):100-107, 1964.

Stefan Reichelstein and Anna Rohlfing-Bastian. Levelized Product Cost: Concept and decision relevance. The Accounting Review, 90(4):1653-1682, jul 2015. ISSN 00014826. doi: 10.2308/ accr-51009.

Stefan Reichelstein and Anshuman Sahoo. Time of day pricing and the levelized cost of intermittent power generation. Energy Economics, 48:97-108, 2015. ISSN 0140-9883. doi: 10.1016/j.eneco. 2014.12.005.

Stefan Reichelstein and Anshuman Sahoo. Relating product prices to long-run marginal cost: Evidence from solar photovoltaic modules. Contemporary Accounting Research, 35(3):1464-1498, 2018.

REN21. Renewables 2020 Global Status Report. Technical report, REN21, 2020.

Reuters. Wind margin pressures shift from turbines to service market. Online, March 2019. URL https://www.reutersevents.com/renewables/wind-energy-update/ wind-margin-pressures-shift-turbines-service-market. 
J. Rogelj, D. Shindell, K. Jiang, S. Fifita, P. Forster, V. Ginzburg, C. Handa, H. Kheshgi, S. Kobayashi, E. Kriegler, L. Mundaca, R. Séférian, and M. V. Vilariño. Global Warming of $1.5^{\circ} \mathrm{C}$. An IPCC Special Report on the impacts of global warming of $1.5^{\circ} \mathrm{C}$ above pre-industrial levels and related global greenhouse gas emission pathways, in the context of strengthening the global response to the threat of climate change, sustainable development, and efforts to eradicate poverty, chapter Mitigation Pathways Compatible with $1.5^{\circ} \mathrm{C}$ in the Context of Sustainable Development. In Press, 2018.

Stephen A Ross, Randolph Westerfield, and Bradford D Jordan. Fundamentals of corporate finance. Tata McGraw-Hill Education, 2008.

RSMeans. RSMeans City Cost Index - 2019, 2020.

Edward S. Rubin, Inês M.L. Azevedo, Paulina Jaramillo, and Sonia Yeh. A review of learning rates for electricity supply technologies. Energy Policy, 86:198-218, nov 2015. doi: 10.1016/j.enpol. 2015.06.011.

O. Schmidt, A. Gambhir, I. Staffell, A. Hawkes, J. Nelson, and S. Few. Future cost and performance of water electrolysis: An expert elicitation study. International Journal of Hydrogen Energy, 42 (52):30470-30492, 2017a. ISSN 03603199. doi: 10.1016/j.ijhydene.2017.10.045. URL https: //doi.org/10.1016/j.ijhydene.2017.10.045.

O. Schmidt, A. Hawkes, A. Gambhir, and I. Staffell. The future cost of electrical energy storage based on experience rates. Nature Energy, 6(July):17110, 2017b. ISSN 2058-7546. doi: 10.1038/ nenergy.2017.110.

Oliver Schmidt, Adam Hawkes, Oliver Schmidt, Sylvain Melchior, Adam Hawkes, and Iain Staffell. Projecting the Future Levelized Cost of Electricity Storage Technologies. Joule, pages 1-20, 2019. ISSN 2542-4351. doi: 10.1016/j.joule.2018.12.008. URL https://doi.org/10.1016/j. joule.2018.12.008.

SDI. Technology. The Composition of EV Batteries: Cells?Modules? Packs? Let's Understand Properly! Online, 2021. URL https://www.samsungsdi.com/column/all/detail/54344. html.

SGRE. Annual Report 2019. Technical report, Siemens Gamesa Renewable Energy S.A., 2019. URL https://www.siemensgamesa.com/en-int/-/media/ siemensgamesa/downloads/en/investors-and-shareholders/annual-reports/2019/ siemens-gamesa-renewable-energy-annual-report-2019-en.pdf.

Iain Staffell, Daniel Scamman, Anthony Velazquez Abad, Paul Balcombe, Paul E. Dodds, Paul Ekins, Nilay Shah, and Kate R. Ward. The role of hydrogen and fuel cells in the global energy 
system. Energy and Environmental Science, 12(2):463-491, 2019. ISSN 17545706. doi: 10.1039/ c8ee01157e.

Bjarne Steffen. Estimating the cost of capital for renewable energy projects. Energy Economics, 88:104783, 2020. ISSN 01409883. doi: 10.1016/j.eneco.2020.104783.

Bjarne Steffen, Martin Beuse, Paul Tautorat, and Tobias S. Schmidt. Experience Curves for Operations and Maintenance Costs of Renewable Energy Technologies. Joule, 4(2):359-375, 2020. ISSN 25424351. doi: 10.1016/j.joule.2019.11.012. URL https://doi.org/10.1016/j.joule. 2019.11.012.

R. Swanson. The silicon photovoltaic roadmap. Stanford Energy Seminar, 2011.

Tax Foundation. Federal Corporate Income Tax Rates. 11.11.2020, 2012.

Tax Foundation. State Corporate Income Tax Rates and Brackets for 2020, 2020.

Robert Thresher, Michael Robinsion, and Paul Veers. Wind energy technology: current status and R\&D future. Technical report, National Renewable Energy Lab, 2008.

Jean Tirole. The theory of industrial organization. MIT press, 1988.

I. Tsiropoulos, D. Tarvydas, and N. Lebedeva. Li-ion batteries for mobility and stationary storage applications. Technical report, European Comission, 2018.

U.S. Department of Energy. Business Energy Investment Tax Credit (ITC), 2016. URL https: //energy.gov/savings/business-energy-investment-tax-credit-itc.

U.S. IRS. Publication 946 (2019), How To Depreciate Property, 2019. URL https://www.irs. gov/publications/p946.

Vestas. Annual Report 2019. Technical report, Vestas Wind Systems A/S, 2019. URL https://www.vestas.com/ /media/vestas/investor/investor\%20pdf/financial\% 20reports/2019/q4/2019_annual_report.pdf.

Eric Williams, Eric Hittinger, Rexon Carvalho, and Ryan Williams. Wind power costs expected to decrease due to technological progress. Energy Policy, 106:427-435, 2017. ISSN 03014215. doi: https://doi.org/10.1016/j.enpol.2017.03.032. URL https://www.sciencedirect. com/science/article/pii/S0301421517301763

Ryan Wiser and Mark Bolinger. 2015 Wind Technologies Market Report. Technical report, U.S. Department of Energy, August 2016. URL https://www.energy.gov/sites/default/files/ 2016/08/f33/2015-Wind-Technologies-Market-Report-08162016.pdf. 
Ryan Wiser, Mark Bolinger, Ben Hoen, Dev Millstein, Joe Rand, Galen Barbose, Naïm Darghouth, Will Gorman, Seongeun Jeong, Andrew Mills, and Ben Paulos. Wind Technologies Market Report. Technical report, Berkeley Lab, 2020.

David Wozabal, Christoph Graf, and David Hirschmann. The effect of intermittent renewables on the electricity price variance. OR Spectrum, 38(3):687-709, 2016. ISSN 14366304. doi: 10.1007/s00291-015-0395-x.

Theodore P. Wright. Factors affecting the cost of airplanes. Journal of the Aeronautical Sciences, 3(4):122-128, 1936.

Sonia Yeh and Edward S. Rubin. A review of uncertainties in technology experience curves. Energy Economics, 34(3):762-771, 2012. ISSN 0140-9883. doi: https://doi.org/10.1016/j.eneco.2011.11. 006. URL https://www.sciencedirect.com/science/article/pii/S0140988311002805.

CF Yu, WGJHM Van Sark, and EA Alsema. Unraveling the photovoltaic technology learning curve by incorporation of input price changes and scale effects. Renewable and Sustainable Energy Reviews, 15(1):324-337, 2011.

Micah S. Ziegler and Jessika E. Trancik. Re-examining rates of lithium-ion battery technology improvement and cost decline. Energy \& Environmental Science, 2021. 